Provided for non-commercial research and education use. Not for reproduction, distribution or commercial use.

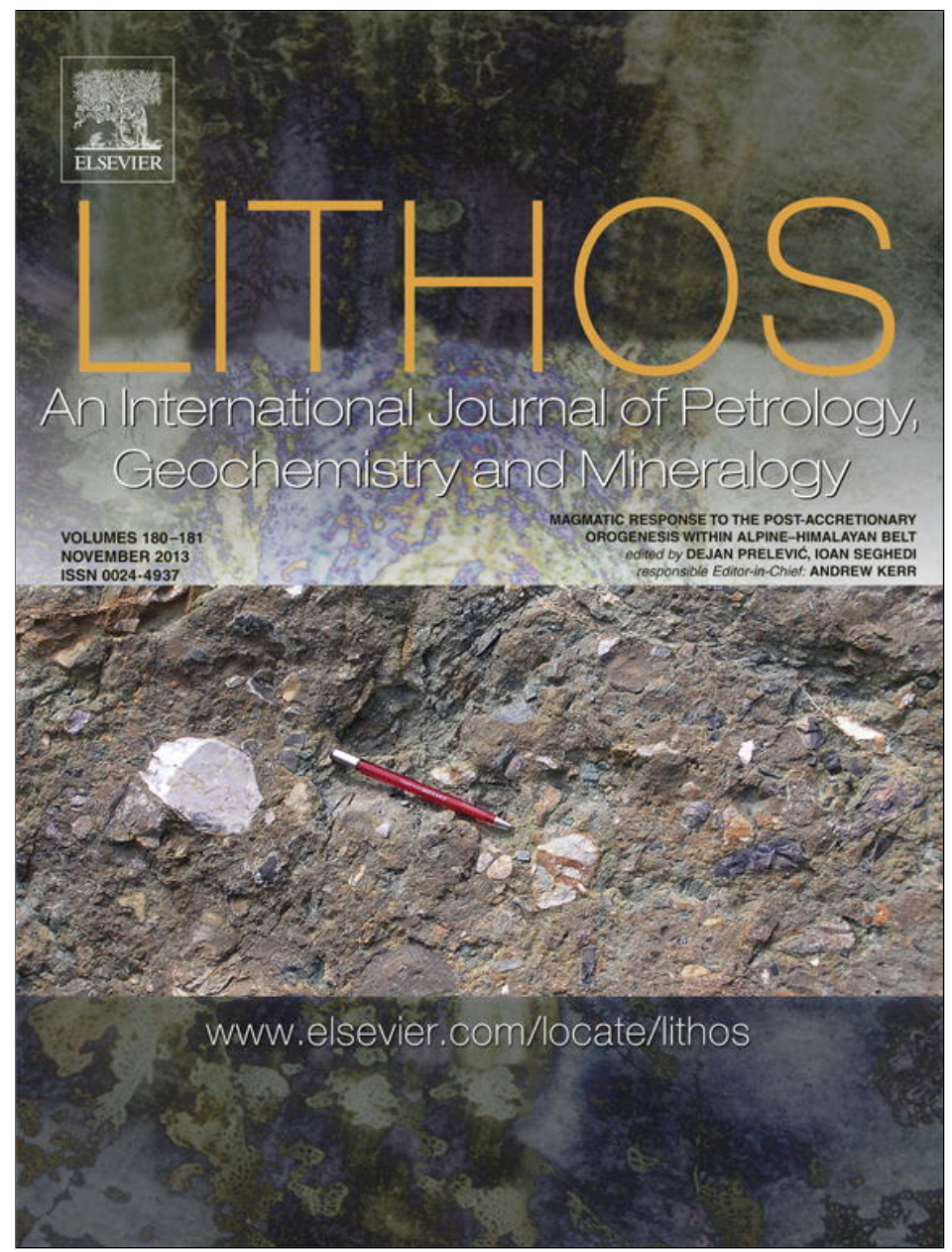

This article appeared in a journal published by Elsevier. The attached copy is furnished to the author for internal non-commercial research and education use, including for instruction at the authors institution and sharing with colleagues.

Other uses, including reproduction and distribution, or selling or licensing copies, or posting to personal, institutional or third party websites are prohibited.

In most cases authors are permitted to post their version of the article (e.g. in Word or Tex form) to their personal website or institutional repository. Authors requiring further information regarding Elsevier's archiving and manuscript policies are encouraged to visit:

http://www.elsevier.com/authorsrights 


\title{
Geochronology, geochemistry and isotope tracing of the Oligocene magmatism of the Buchim-Damjan-Borov Dol ore district: Implications for timing, duration and source of the magmatism
}

\author{
St. Lehmann ${ }^{\text {a }}$, J. Barcikowski ${ }^{\text {a }}$, A. von Quadt ${ }^{\text {a,* }}$, D. Gallhofer ${ }^{\text {a }}$, I. Peytcheva ${ }^{\text {a,c }}$, C.A. Heinrich ${ }^{\text {a }}$, T. Serafimovski ${ }^{\text {b }}$ \\ a Institute of Geochemistry and Petrology, ETH Zurich, Clausiusstrasse 25, 8092 Zurich, Switzerland \\ b Faculty of Mining and Geology, Goce Delcev 89, 92000 Stip, Macedonia \\ c Geological Institute, Bulgarian Academy of Science, Sofia, Bulgaria
}

\section{A R T I C L E I N F O}

\section{Article history:}

Received 12 February 2013

Accepted 11 September 2013

Available online 20 September 2013

\section{Keywords:}

Cu porphyry

$\mathrm{U}-\mathrm{Pb}$ zircon geochronology

Magmatic evolution

Geochemistry

LA-ICP-MS analyses

\begin{abstract}
A B S T R A C T
Timing, source and magmatic evolution of the intrusions in the Buchim-Damjan-Borov Dol ore district of the Former Yugoslav Republic of Macedonia (F.Y.R.O.M.) have been studied. They intrude the Circum Rhodope Unit close to the contact with the Vardar Zone and are a part of the Late Eocene-Oligocene Macedonian RhodopeNorth Aegean belt. The magmatism at Buchim-Damjan-Borov Dol occurred between $24.04 \pm 0.77$ and $24.51 \pm 0.89 \mathrm{Ma}$, as indicated by chemical-annealing (CA)-LA ICP-MS zircon dating. Major element, trace and rare earth element analyses have been performed on the various intrusive rocks. All ore bearing magmas were classified as trachyandesitic, except the youngest intrusion which is not associated with mineralization; the Black Hill locality $(24.04 \pm 0.77 \mathrm{Ma})$ shows a trachytic composition. The distribution of the trace elements, enrichment of large ion lithophile elements (LILE) and depletion in high field strength elements (HFSE), indicates subduction-related magmatism; most of the magmas follow a calc-alkaline fractionation trend with shoshonitic affinities; additionally, $\mathrm{Sr} / \mathrm{Y}$ (10 to 90 ) and La/Yb values show some similarities to adakite-like magmas. $\mathrm{Sr}$ and $\mathrm{Nd}$ isotope ratios $\left(\mathrm{Sr}_{i}=0.70658\right.$ to 0.70740 and $\left.\mathrm{Nd}_{i}=0.512425-0.512497\right)$ show that the magmatic products were slightly contaminated by continental crust material, e.g., the Variscan/Cadomian basement. In the Late EoceneOligocene belt the magmatism between 29 and $35 \mathrm{Ma}$ is dominated by crustal melting with an increase in the mantle contribution between 20 and $27 \mathrm{Ma}$. We suggest the following scenario for the magmatic history of the Buchim-Damjan-Borov Dol ore district: a slab rollback of an oceanic slab located further to the SW which led to extensional and compressional features in upper levels of the continental crust. In the middle to upper crust three consecutive crystallization stages occurred at variable depths as indicated by amphibole zonation. Mixing of newly formed crust with mantle-like affinities and continental crust material in variable degrees during the ascent of the magma can explain all geochemical characteristics. The magma crystallized as dykes or stocks near the Earth's surface $(>1 \mathrm{~km})$ after its final emplacement and contemporaneous hydrothermal activity led to different mineralization styles depending on the lithology of the host rocks.
\end{abstract}

(C) 2013 Elsevier B.V. All rights reserved.

\section{Introduction}

The Buchim-Damjan-Borov Dol ore district is located in the eastern part of F.Y.R. of Macedonia (F.Y.R.O.M.) and is part of the Alpine-BalkanCarpathian-Dinarides metallogenetic belt (Heinrich and Neubauer, 2002). The intrusions of the district belong to a Late EoceneOligocene magmatic zone (Harkovska et al., 1989), which cross cuts older tectonic structures (Fig. 1; Schefer et al., 2011), and occur within the Circum Rhodope unit according to the map compilation of Schmid et al. (2011). The Late Oligocene intrusions are partly associated with

* Corresponding author at: ETH Zurich, Department of Earth Sciences, Switzerland, Tel.: + 4144 6323724; fax: + 41446321827 .

E-mail address: vonquadt@erdw.ethz.ch (A. von Quadt). economic and non-economic ore mineralization (Fig. 1; Table 1). Although the mine at Buchim has been known since ancient times, it was not explored in detail until the 1970's (Serafimovski et al., 2010). Since 1979, 80 Mt of the 120 Mt estimated reserves have been mined, with an average ore grade of $0.34 \% \mathrm{Cu}$ and $0.35 \mathrm{~g} / \mathrm{t} \mathrm{Au}$ (Cifliganec, 1993; Serafimovski et al., 1996, 2010; Volkov and Serafimovski, 2010). The deposit consists of four ore bodies, of which three are related to porphyry fingers and one is suggested to represent supergene mineralization (Cifliganec, 1993; Serafimovski and Boev, 1996; Serafimovski et al., 2010; Volkov and Serafimovski, 2010). The intrusions are of andesitic to trachyandesitic composition with intrusion ages ranging between 27.5 and 24.9 Ma (K/Ar whole rock ages) (Cifliganec, 1993; Serafimovski et al., 2010). The Borov Dol porphyry is located south of the Buchim deposit (Fig. 2). It was discovered in 1930 (Cifliganec, 1993; Volkov and Serafimovski, 2010) and in contrast to the Buchim 


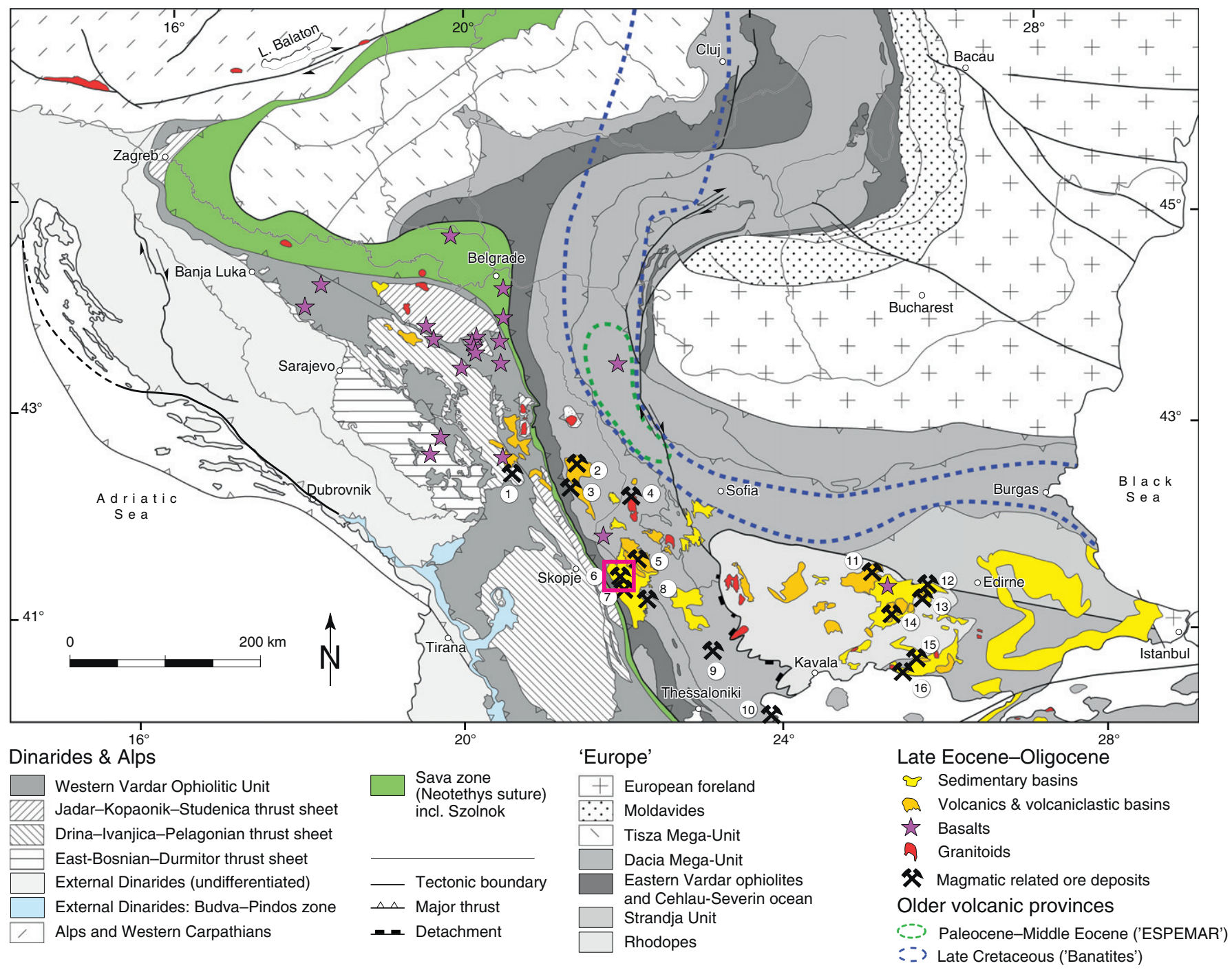

Fig. 1. Distribution of magmatic related ore deposits of Late Eocene to Oligocene age on the Balkan Peninsula. The red inlet refers to the studied area (Fig. 2). For references to the numbers, see Table 1.

Modified map after Schefer et al., 2011.

porphyry, different tuff layers host the mineralization. The reserves are $30 \mathrm{Mt}$ with an average grade of $0.3 \% \mathrm{Cu}$ and $0.2 \mathrm{~g} / \mathrm{t}$ Au (Cifliganec, 1993). The Damjan skarn deposit is located between Borov Dol and Buchim (Fig. 2). The reserves are approximately $10 \mathrm{Mt}$ of ore with an average iron content of 35\% and it was an active mine between 1968 and 1992 (Volkov and Serafimovski, 2010). Finally, the barren Black Hill intrusion north of the district (Fig. 2) shows a trachytic composition. Various mineralogical and fluid inclusion studies have been conducted in the district but only a limited amount of data related to the magmatic history have been published (Cifliganec, 1993; Serafimovski and Boev, 1996; Serafimovski et al., 2010; Strashimirov et al., 1996; Volkov and Serafimovski, 2010).

The focus of this study is the magmatic history of the BuchimDamjan-Borov Dol ore district, which leads to several scientific questions: Which tectonic processes induced the magmatic event? How did the magma evolve during ascent? What is the age of the intrusions? Does the tuff found around Borov Dol have its origin in a volcanic eruption from the Borov Dol magmatism?

Geochemical bulk rock analysis was performed in order to classify the different intrusions and to identify possible geochemical differences among them using XRF analyses, in-situ LA-ICP-MS analyses and thermal-ionization mass spectrometry (TIMS) for Sr-Nd measurements. The magmatic ages were determined by LA-ICP-MS U/Pb analyses on single zircon grains; additionally, trace elements were measured on zircons.

\section{Geological setting}

\subsection{Regional geological setting}

SE Europe underwent a complex Alpine tectonic evolution. The Srednogorie zone, Kraishte and the Rhodope Massif in Serbia, Macedonia and Bulgaria were sites of extensive westward/southward younging magmatic activity, starting in Jurassic to Cretaceous time with the closure of the Vardar ocean (Pe-Piper, 1998; Pe-Piper and Piper, 2002; Schmid et al., 2008). In Middle Jurassic, the Vardar oceanic basin began to close, when the Adriatic plate was subducted below the Eurasian continent (Bortolotti et al., 2005). After the obduction of the Eastern and Western Vardar Ophiolitic Units in the latest Jurassic or Early Cretaceous, the post-collisional convergence across the Sava zone produced a thickened crust north to northeast of the suture, which crops out within the Rhodope Mountains (Burchfiel et al., 2008; Saccani et al., 2008). Metamorphism, plutonic activity, low-angle faults and shear zones were created during the thickening of the crust (Burchfiel et al., 2008). The end of the subduction and collision event and related compression occurred in the Priabonian (latest Eocene) 
Table 1

Ore deposits which are related to Late Eocene to Oligocene magmatism.

\begin{tabular}{|c|c|c|c|c|c|c|}
\hline & Deposit & Country & Deposit type & Metals & Age & References \\
\hline 1 & Trepca & Kosovo & $\begin{array}{l}\text { Breccia pipe with skarns and } \\
\text { stratiform mantos }\end{array}$ & $\mathrm{Pb}, \mathrm{Zn}, \mathrm{Ag}(\mathrm{Ag})$ & $23-26 \mathrm{Ma}$ & Strmic Palinkas et al. (2013) \\
\hline 2 & Lece & Serbia & $\begin{array}{l}\text { Breccia pipe with skarns and } \\
\text { stratiform mantos }\end{array}$ & $\mathrm{Pb}, \mathrm{Zn}, \mathrm{Ag}(\mathrm{Ag})$ & $29.2 \mathrm{Ma}$ & Serafimovski et al. (1997) \\
\hline 3 & Kiseljak & Serbia & Porphyry-Cu-Au & $\mathrm{Cu}, \mathrm{Au}$ & $12-23 \mathrm{Ma}$ & Serafimovski et al. (2010) \\
\hline 4 & Surdulica & Serbia & Porphyry-Mo & & $36 \pm 1 \mathrm{Ma}$ & M. Antic \\
\hline 5 & Kratovo-Zletovo & Macedonia & Porphyry-Cu-Au & $\mathrm{Pb}, \mathrm{Zn}, \mathrm{Ag}(\mathrm{Ag})$ & $26.5 \mathrm{Ma}$ & Serafimovski and Boev (1996) \\
\hline 6 & $\begin{array}{l}\text { Buchim-Damjan-Borov Dol ore } \\
\text { district }\end{array}$ & Macedonia & Porphyry-Cu-Au, Skarn & $\mathrm{Cu}, \mathrm{Au},(\mathrm{Ag}), \mathrm{Fe}$ & $24.0-24.5 \mathrm{Ma}$ & \\
\hline 7 & Ilovica & Macedonia & Porphyry-Cu-Au & $\mathrm{Cu}, \mathrm{Au},(\mathrm{Ag})$ & $\begin{array}{l}\text { 30.12-30.31 Ma U/ } \\
\mathrm{Pb}\end{array}$ & Georgiev et al. (2012a,b) \\
\hline 8 & Jekario & Greece & Porphyry-Cu-Au & $\mathrm{Cu}, \mathrm{Au}(\mathrm{Ag})$ & $22-34 \mathrm{Ma}$ & Frei (1992) \\
\hline 9 & Vathi & Greece & Porphyry-Cu-Au & $\mathrm{Cu}, \mathrm{Au}(\mathrm{Ag})$ & $17-18 \mathrm{Ma} \mathrm{U} / \mathrm{Pb}$ & Frei $(1992)$ \\
\hline 10 & $\begin{array}{l}\text { Kassandra (Olympias, Mavres } \\
\text { Petres, Madem Lakkos, Skouries) }\end{array}$ & Greece & Various & various & $20-30 \mathrm{Ma}$ & Gilg et al. (1992), Frei (1992) \\
\hline 11 & Spahievo & Bulgaria & $\begin{array}{l}\text { Volcanic hosted intermediate } \\
\text { sulfidation }\end{array}$ & $\mathrm{Pb}, \mathrm{Zn}, \mathrm{Cu},(\mathrm{Au}-\mathrm{Ag})$ & 34.5-31.76 Ma & Singer and Marchev (2000) \\
\hline 12 & Lozen & Bulgaria & $\begin{array}{l}\text { Volcanic hosted intermediate } \\
\text { sulfidation }\end{array}$ & $\mathrm{Pb}, \mathrm{Zn}, \mathrm{Cu},(\mathrm{Au}-\mathrm{Ag})$ & 36.5-35 Ma K/Ar & Lilov et al. (1987) \\
\hline 13 & Madjarovo & Bulgaria & $\begin{array}{l}\text { Volcanic hosted intermediate } \\
\text { sulfidation }\end{array}$ & $\mathrm{Pb}, \mathrm{Zn}, \mathrm{Cu},(\mathrm{Au}-\mathrm{Ag})$ & 32.7-32.2 Ma & Marchev and Singer (2002) \\
\hline 14 & Pcheloyad\&Zvezdel & Bulgaria & $\begin{array}{l}\text { Volcanic hosted intermediate } \\
\text { sulfidation }\end{array}$ & $\mathrm{Pb}, \mathrm{Zn}, \mathrm{Cu},(\mathrm{Au}-\mathrm{Ag})$ & 31.1-31.9 Ма & Marchev et al. (2004) \\
\hline 15 & Sappes & Greece & Volcanic hosted high sulfidation & $\mathrm{Cu}, \mathrm{Au}(\mathrm{Ag})$ & 33.5-19.6 Ma K/Ar & Pecskay et al. (2003) \\
\hline 16 & Perama \& Maronia & Greece & Volcanic hosted high sulfidation & $\mathrm{Cu}, \mathrm{Au}(\mathrm{Ag})$ & $<29.8-28.7 \mathrm{Ma}$ & $\begin{array}{l}\text { Marchev et al. (2010); Kyriakopoulus } \\
\text { (1987) and Del Moro et al. (1988) via } \\
\text { Melfos et al. (2002) }\end{array}$ \\
\hline $17 / 10$ & Skouries & Greece & Porphyry-Cu-Au-PGE & $\mathrm{Cu}, \mathrm{Au}, \mathrm{PGE}$ & $19 \mathrm{Ma}$ & Frei (1992) \\
\hline
\end{tabular}

(Dumurdzanov et al., 2005). Remnants of the obducted Eastern and Western Vardar Ophiolitic Units are still preserved and crop out in Central F.Y.RO.M., Northern Greece, Serbia and Northwest Turkey (Burchfiel et al., 2008; Schmid et al., 2008). Two important subductionrelated magmatic belts can be distinguished based on time relationships: (a) the Late Cretaceous magmatic zone (Popov, 1981, 1987), known as the Apuseni-Banat-Timok-Srednogorie (ABTS) magmatic and metallogenic belt (Popov et al., 2002) and (b) the Late Eocene-Early Oligocene magmatic zone, known as the Macedonian-Rhodope-North Aegean belt (Harkovska et al., 1989). The Late Cretaceous magmatic evolution of the ABTS belt (Georgiev et al., 2012a,b; Kolb et al., 2012; von Quadt et al., 2005) is not restricted to the tectonic zone of Srednogorie and Eastern Serbia, the magmatic evolution is continuing into the Rhodope Massif (Marchev et al., 2004; Marchev et al., 2005; von Quadt et al., 2005) and Ridanj Krepoljin (Kolb et al., 2012). The magmatism within the belt has a highly variable composition, represented by tholeiitic, calc-alkaline, shoshonitic and ultra-K extrusive and intrusive rocks with unradiogenic initial $\mathrm{Sr}$ and radiogenic $\mathrm{Nd}$ isotopes. More recently, von Quadt et al. (2005), Georgiev et al. (2009) and Kolb et al. (2012) proposed the model of a slab rollback and rifting to explain the observed across-arc younging trends of the magmatism from north ( $90 \mathrm{Ma})$ to south $(\sim 67 \mathrm{Ma})$.

In late Eocene to Oligocene a transition from a convergent tectonic setting to a more extensional tectonic setting occurred within the area, consequently leading to a progressive thinning of the lithosphere (Burchfiel et al., 2008; Burg, 2012). Different types of sedimentary basins formed during extension, most of them associated with major extensional faults and magmatism, which characterize a wide region from eastern F.Y.R.O.M. to the eastern Rhodope mountains (Burchfiel et al., 2008). In the eastern F.Y.RO.M., these Bartonian basins (stratigraphic age) are associated with Eocene-Oligocene intermediate to felsic volcanics and small intrusive bodies, which illustrate the dynamic setting of alternation between regional shortening and regional extension (Burchfiel et al., 2008; Dumurdzanov et al., 2005). The Late Eocene to Oligocene magmatic belt of Eastern F.Y.RO.M. extends into the Rhodope Massif of Bulgaria and Greece (Marchev et al., 2004), Serbia (Cvetković et al., 2000, 2004) and into Macedonia (Fig. 1), it was preceded by a major episode of extension which started with block faulting and formation of E-W to NNW-SSE sedimentary basins (Burchfiel et al., 2008). The Late Eocene-Oligocene magmatic belt evolved from K-rich trachybasalts ( $34 \mathrm{Ma}$ ) via shoshonites, calc-alkaline and high-K calcalkaline basalts ( 33 to $31 \mathrm{Ma}$ ) to alkaline basalts (2826 Ma; Marchev et al., 2004, 2005; Cvetković et al., 2000; Prelević et al., 2005). The origin of this very heterogeneous magmatism has generally been explained to be related to the postcollisional collapse of the Dinaride orogen (Late Oligocene) followed by the extension in the Pannonian basin (Miocene) and in the Aegean area (Pliocene) (Cvetković et al., 2000, 2004; Koroneos et al., 2011; Prelević et al., 2005; Schefer et al., 2011; Van Hinsbergen and Schmid, 2012). It was also demonstrated that the mafic magmas resulted from the melting of depleted mantle metasomatized by earlier subduction processes. In this context, the ultrapotassic magmas are considered to be melts derived from a metasomatized mantle (Prelević et al., 2005). The petrogenesis of felsic and intermediate rocks has been explained by the partial melting of lower crustal rocks and subsequent evolution processes including crystal fractionation, assimilation and magma mixing (e.g., Koroneos et al., 2011). Recent precise radiometric dating demonstrated that numerous magmatic rocks in Dinarides (Serbia), the Kraishte zone, Srednogorie zone and the Rhodope Massif are in the range of $\sim 56$ to $18 \mathrm{Ma}$ (e.g., Georgiev et al., 2012a,b; Jahn-Awe et al., 2010, 2012; Ovtcharova et al., 2004; Peytcheva et al., 2012; Schefer et al., 2011; Soldatos et al., 2008).

\subsection{Geology of the Buchim-Damjan-Borov Dol ore district}

The Buchim-Damjan-Borov Dol ore district is located in the Circum Rhodope Unit (Schmid et al., 2008) and is about $50 \mathrm{~km}^{2}$ in size. Several NW-SE striking thrust faults divide the district into different tectonic units (Fig. 2 and geological map Kavadarci, see Hristov et al., 1973.). They are related to an Early Miocene crustal shortening, which lead to an uplift of the Buchim area of about $800 \mathrm{~m}$ in the Borov Dol area, which in turn is uplifted $800 \mathrm{~m}$ relative to the area located to its west (based on field observations, there are different exposure levels between Buchim and Borov Dol Fig. 2B). The preservation of Eocene 


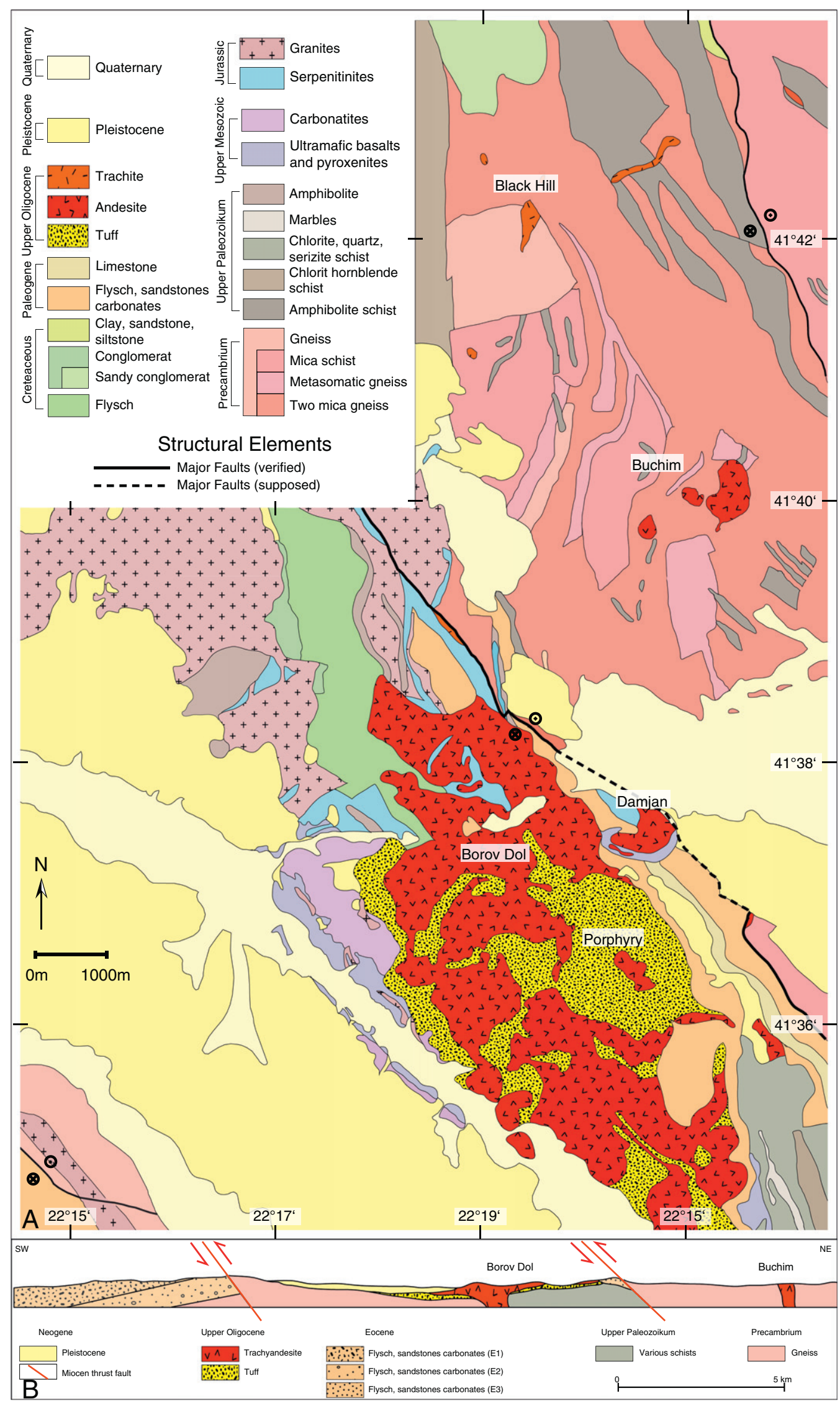

Fig. 2. A: Geological map of the Buchim-Damjan-Borov Dol ore district, modified after an unpublished mine map and Hristov et al. (1973.); B: Schematic cross section through the Buchim-Damjan-Borov Dol ore district modified after Hristov et al. (1973.). 
strata decreases towards the NE due to erosion. Therefore, deeper geological units, such as Paleozoic schists and Precambrian gneisses, are increasingly exposed towards the NE (Fig. 2). Numerous intrusions are found in the area, among them the Buchim, Damjan, Borov Dol and Black Hill intrusions. After the emplacement of the porphyry intrusions a later thrust faulting leads to an uplift of the Buchim area in contrast to the Borov Dol-Damjan region (Figs. 1, 2, 3). The intrusions are of variable sizes and intrude diverse host rocks of different tectonic units. The Damjan skarn deposit is located about $4 \mathrm{~km}$ south of Buchim and is hosted by supposedly Late Cretaceous flysch sediments (Fig. 2). Several andesite/trachyandesite intrusions, which are embedded in volcanic tuffs, host the Borov Dol copper mineralization (Cifliganec, 1993; Serafimovski et al., 2010). The magmatic complex of Borov Dol offers a view into a shallow magma chamber. It is located $8 \mathrm{~km} \mathrm{SSW}$ of Buchim also in the Circum Rhodope belt. The Buchim porphyry $\mathrm{Cu}-\mathrm{Au}$ deposit is related to andesitic dykes and is the main focus of this project. Cifliganec (1993) dated the Buchim andesites by $\mathrm{K}-\mathrm{Ar}$ whole rock methods and they yielded ages between 27.5 and $24.9 \mathrm{Ma}$ and the Damjan and Borov Dol andesites range in age from 28 to $26.5 \mathrm{Ma}$. The faults in the area mostly trend NNW-SSE and NNE-SSW, and the distribution of the intrusions largely follows them (Serafimovski and Boev, 1996).

\subsection{Buchim deposit}

The deposit is made up of a magmatic complex consisting of three proven finger-like porphyry stocks (Central, Vrsnik and Bunardzik). The Cukar ore body, a supergene mineralization (Cifliganec, 1993) has already been mined out (Figs. 2, 4A). According to new geological field observations a magmatic stock is assumed below the Cukar ore body (personal communication with local mining geologists; Fig. 3A). Unfortunately, drill cores are now unavailable and the waste of the open pit has accumulated on the remains of the body. The mineralization of the Central porphyry is cut by the Vrsnik intrusion. This relationship is visible in mineralized gneiss clasts, which contain veins that are cut off by the magmatic intrusion (Fig. 4B). Accordingly, the Central intrusion is older than the Vrsnik intrusion (Fig. 3B). The Central ore body is emplaced in varied Precambrian gneisses, which rarely contain lenses of Precambrian crystalline schist. The morphology of the ore body is similar to a cylinder with a diameter of $500 \mathrm{~m}$, surrounding an andesitic stock with a vertical depth of more than $500 \mathrm{~m}$ (Fig. 3B). The most significant ore mineral is chalcopyrite, which is accompanied by pyrite, magnetite, hematite, cubanite, valerite, native gold, bornite and others (Serafimovski and Boev, 1996). The copper mineralization is primary (hypogene). Gneiss xenocrysts in the magmatic stock contain pyrite veinlets, which are cut off by the magmatic intrusion (Fig. 4C). Therefore, the present magmatic rock overprints an earlier magmatic and hydrothermal event. The Bunardzik ore body (Fig. 3) shows the same mineralization as the Central ore body, but the ore-minerals are scarcer (Cifliganec, 1993). The mineralization of the Bunardzik ore-body is also hosted by Precambrian gneisses of the Circum Rhodope unit. In contrast to the Central ore body, however, the Bunardzik ore body is crescent shaped adjacent to the andesitic intrusion (Cifliganec, 1993). The dimensions of the body are $300 \times 100 \mathrm{~m}$ at the surface with a $300 \mathrm{~m}$ depth (Cifliganec, 1993). The Vrsnik ore body (Fig. 3), which is located east of the Central ore body, is ellipsoidal in shape. In contrast to the
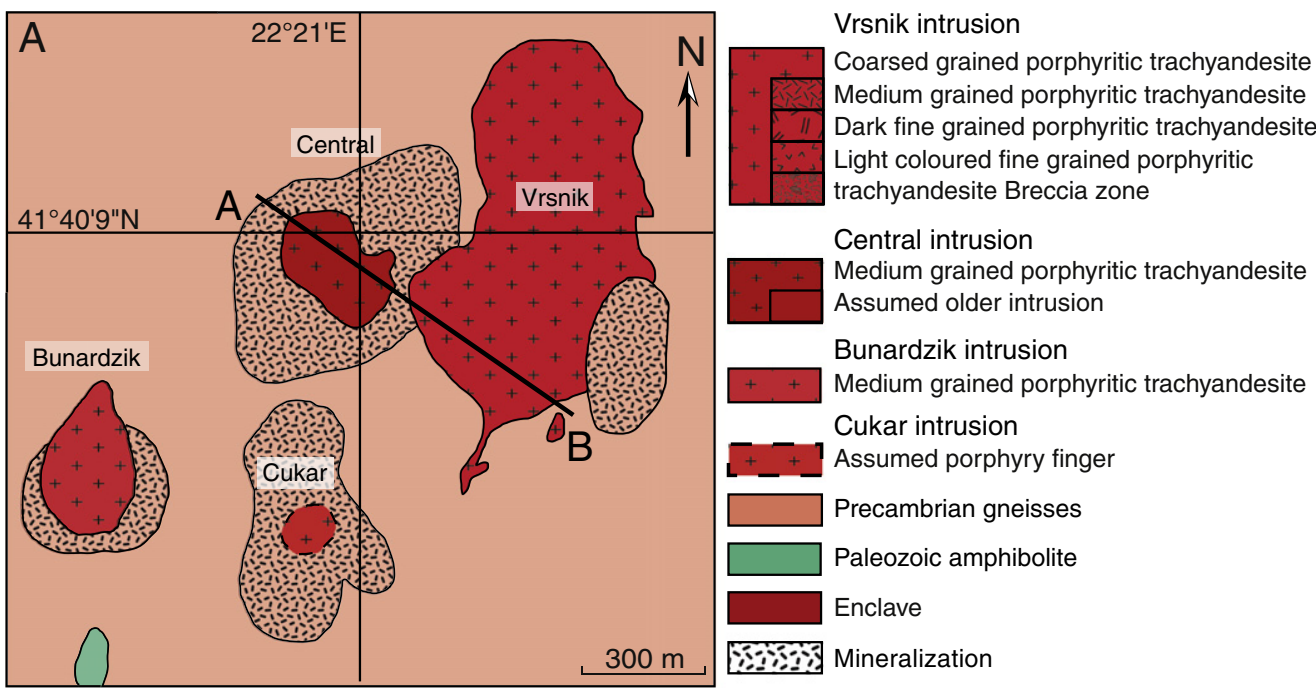

\section{N.N.}

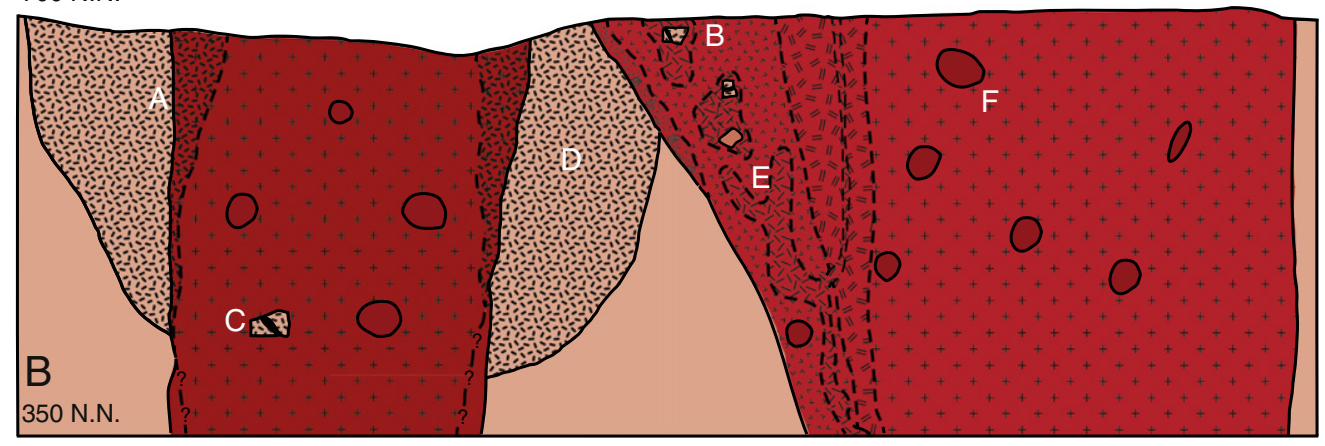

\begin{tabular}{ll}
\hline $\mathrm{A}$ & $1000 \mathrm{~m}$
\end{tabular}

Fig. 3. A: Geological map of the Buchim mine, with the cross-section A-B. B: Cross section A-B showing the central and Vrsnik intrusion and the associated mineralization. Modified map after Serafimovski and Boev (1996). 

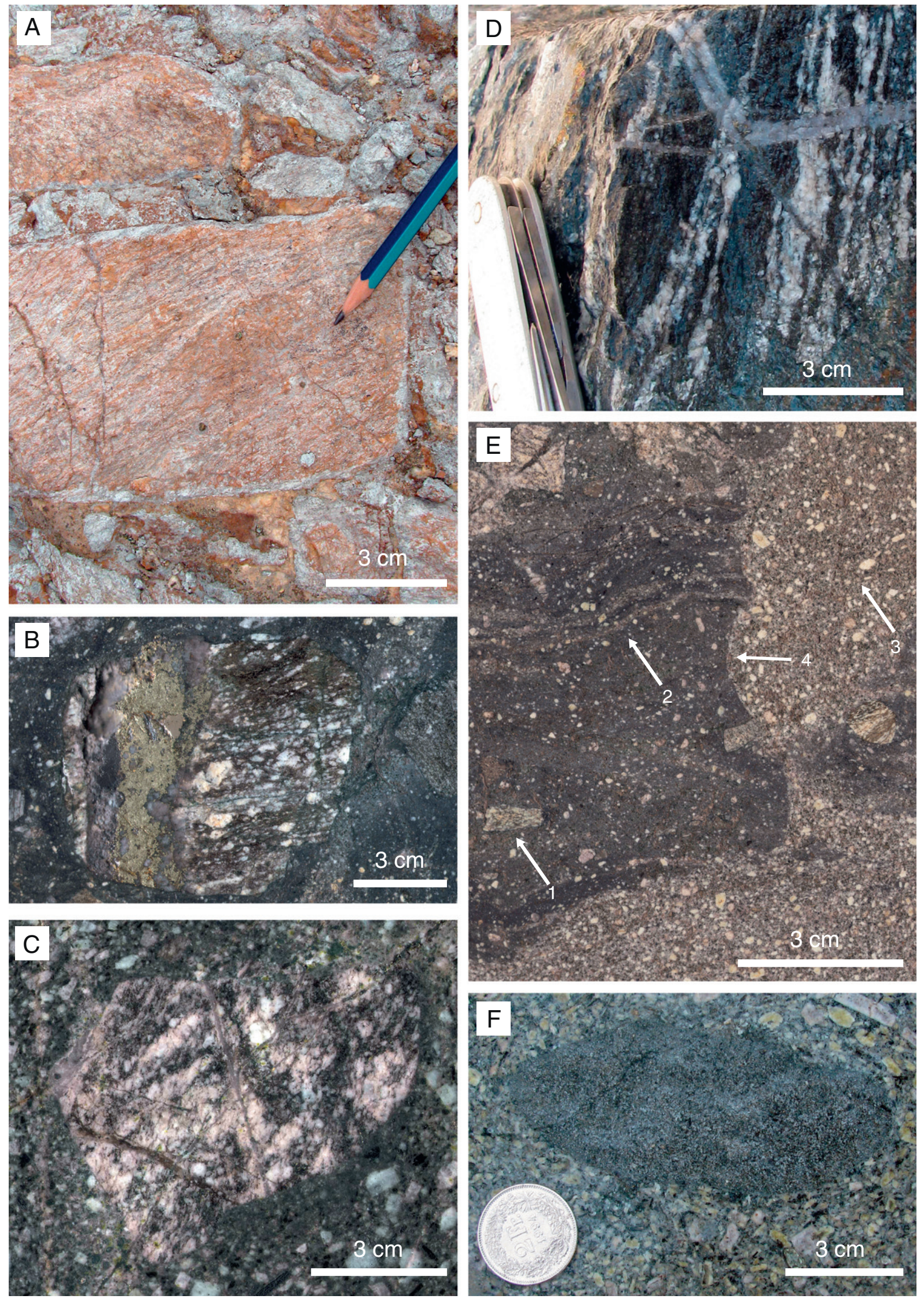

Fig. 4. Photographs of the Buchim intrusions. A: Phyllic to argillic altered breccia zone of the central intrusion. B: Gneiss clast in the Vrsnik intrusion which contains a quartz-pyrite vein of the earlier central mineralization. C: Gneiss clast of the central intrusion containing veins which were cut off by the trachyandesite intrusion. D: Mineralized gneiss showing magnetite vein, which cut through earlier quartz-pyrite vein. E: Mingling texture of the Vrsnik intrusion (white arrows). F: Enclave of the Vrsnik intrusion. 
already mentioned bodies, the mineralization occurs only partially in the host rock of the metamorphic basement. The main part is hosted by the intrusion. The ore body is of small size, with a depth of about $80 \mathrm{~m}$, a surface length of $300 \mathrm{~m}$ and a surface width of $200 \mathrm{~m}$ (Cifliganec, 1993).

\section{Results}

\subsection{Mineralogy and petrography}

The trachyandesites of the Buchim-Damjan-Borov Dol ore district display porphyritic textures (Fig. 5). Major phenocrysts include plagioclase, amphibole, sanidine and biotite and constitute $35-45 \%$ of the rock volume (Table 2). The microcrystalline matrix consists of plagioclase, amphibole, sanidine, biotite, quartz and accessory mineral phases (apatite, zircon, magnetite and rarely allanite and sphene). Plagioclase phenocrysts $\left(\mathrm{An}_{0.25-0.42}\right)$ show both normal and inverse oscillatory zoning and rarely exhibit resorbed crystal rims. Amphibole crystals are frequently overgrown by large plagioclase phenocrysts (Fig. 5A). The amphibole phenocrysts are, with a few exceptions, optically homogeneous and are all calcic in composition (Leake et al., 1997). They are mostly of ferropargasitic composition and occasionally have rims $(\sim 10 \mu \mathrm{m})$ of edenite, magnesio-hornblende or pargasite (Fig. 5B). Some amphibole phenocrysts exhibit rims of small opaque minerals and chlorite. The analyzed sanidine phenocrysts have an orthoclase content of $\mathrm{Or}_{0.68-0.88}$ (Lehmann et al., 2012). Biotite phenocrysts occur as laths with opacitic rims consisting of small opaque minerals. Semiquantitative amphibole-plagioclase thermobarometry after Blundy and Holland (1990) reveals variable crystallization temperatures and depths within single intrusions (Lehmann et al., 2012). The calculated crystallization pressures of the amphiboles in the central intrusion of Buchim range from $7 \mathrm{kbar}$ in the core to $3 \mathrm{kbar}$ at the rims, and the calculated crystallization temperatures range from 880 to $800{ }^{\circ} \mathrm{C}$ (Lehmann et al., 2012). The two feldspar thermometry after Putirka and Fran (2008) yields a feldspar crystallization temperature of 830 to $810{ }^{\circ} \mathrm{C}$, overlapping with the calculated amphibole crystallization temperatures. Most of the trachyandesites show varying degrees of hydrothermal alteration (Table 2). Amphibole phenocrysts are either replaced by shreddy biotite (potassic alteration) or by epidote (propylitic alteration). Sericitization occurs at rims of plagioclase phenocrysts.

\subsection{Vein paragenesis and alteration}

Fieldwork in the Buchim-mine revealed that there are four different vein types connected with the Central-porphyry intrusion. The mineralogy of the veins is briefly summarized below. The first vein type is represented by quartz \pm magnetite \pm hematite \pm pyrite and is followed by a stage of pure magnetite veins (Fig. 4D). The magnetite veins reach a thickness of up to $6 \mathrm{~cm}$. They are cut by a calcite \pm quartz \pm chlorite \pm molybdenite \pm pyrite \pm chalcopyrite assemblage, which represents the high grade ore. The last step of the vein paragenesis comprises calcite \pm chlorite \pm pyrite veins. The last two generations caused strong alteration (Fig. 4A), and features of potassic, propylitic, phyllic and argillic alteration were observed. The samples mainly show features of potassic and propylitic alteration. They show different degrees of those types of alteration, but most samples are only weakly altered. They show no/slight signs of potassic and propylitic alteration on feldspar and amphibole crystals (Table 3 ).

\subsection{Major and trace elements of the igneous rocks}

\subsubsection{Intrusive rocks}

The whole rock geochemical data are presented in Table 3 and are in agreement with published data (Serafimovski et al., 1996, 2010). All intrusions from the Buchim-Damjan-Borov Dol Ore district are high-K to shoshonitic rocks $\left(\mathrm{SiO}_{2}\right.$ 59-63 wt.\%; $\mathrm{K}_{2} \mathrm{O}$ 3.5-6 wt.\%; Table 3; Le Maitre et al., 1989; Müller et al., 1992; Pearce, 1982; Rickwood, 1989). Due to only minor variations in $\mathrm{SiO}_{2}$ content (excluding the mafic enclaves and Black Hill samples), the major elements do not show any trend with changing $\mathrm{SiO}_{2}$ contents. The concentration of some major elements are variable, e.g. for $\mathrm{Na}_{2} \mathrm{O}$ (0.4-6.9 wt.\%), $\mathrm{CaO}$ (1.713.6 wt.\%) and $\mathrm{K}_{2} \mathrm{O}(0.5-5.9 \mathrm{wt} . \%)$. In the major element classification of Hastie et al. (2007) and Le Maitre et al. (1989) the volcanic rocks of the Buchim, Damjan and Borov Dol intrusion plot in the field of trachyandesite, whereas the mafic enclaves show a trachybasaltic composition (Fig. 6A). The Black Hill samples are classified as trachytes (Fig. 6A). On Fig. 6C (Winchester and Floyd, 1977) the samples plot in the andesite or trachyandesite field. The $\mathrm{K}_{2} \mathrm{O}$ vs. $\mathrm{SiO}_{2}$ plot (Fig. 6D) shows that most samples plot in the high-K and shoshonitic field; we cannot exclude that the shift into the shoshonitic field was caused by alteration, e.g. the altered andesite samples (Fig. 6D) show high $\mathrm{K}_{2} \mathrm{O}$ values. Most samples have high $\mathrm{Sr} / \mathrm{Y}$ and $\mathrm{La} / \mathrm{Yb}$ ratio (Fig. $6 \mathrm{~B}, \mathrm{E}$ ) and their multi-element patterns are characterized by depletion in $\mathrm{Nb}$, Ta and $\mathrm{Zr}$, and enrichment of $\mathrm{Pb}$ and $\mathrm{Sr}$ (Fig. 6F); the LILE (large ion lithophile elements) are enriched relative to the HFSE (high field strength elements) (Fig. 6F). These patterns are usually characteristic of subduction related magmatism (e.g. Stolz et al., 1996). The rare earth element (REE) patterns show enrichment in light REE (LREE) compared to heavy REE (HREE) (Fig. 6G). Almost all samples show a slight Eu anomaly. Additionally, several discrimination diagrams like $\mathrm{Zr} / \mathrm{Y}$ vs. $\mathrm{Zr}, \mathrm{Ce} / \mathrm{P}_{2} \mathrm{O}_{5}$ vs. $\mathrm{Zr} / \mathrm{TiO}_{2}$ and Ti vs. $\mathrm{Zr}$ (Müller et al., 1992; Pearce, 1983) point to a continental arc setting.
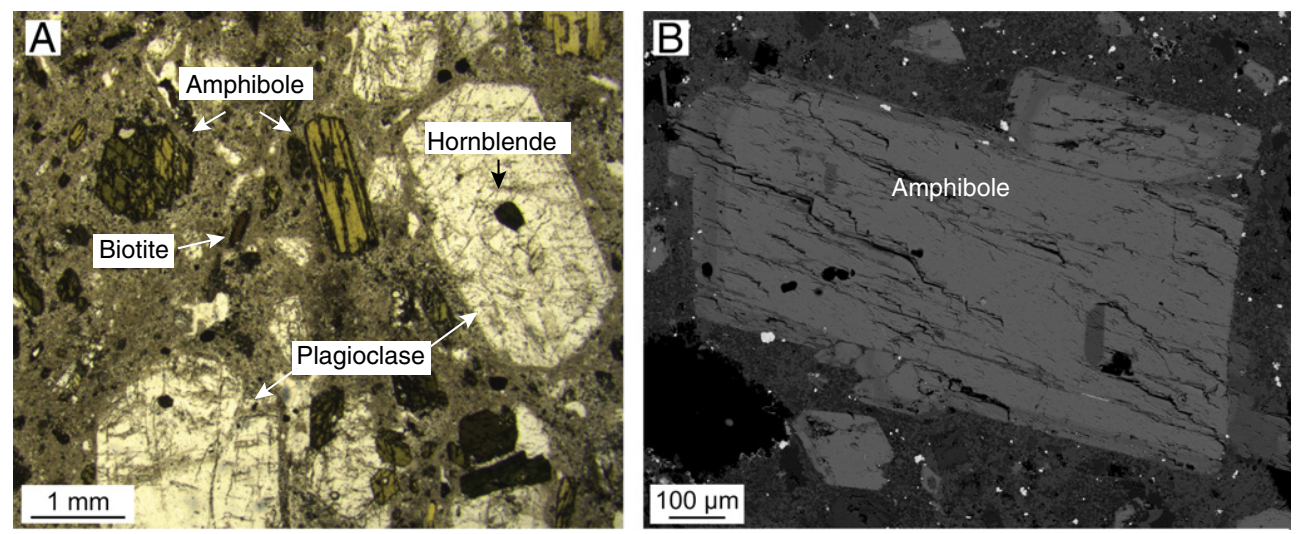

Fig. 5. Thin section micrographs. A: Central andesite intrusion showing the typical porphyritic texture with large plagioclase phenocrysts (approximately 3 mm) enclosing smaller hornblende (approx. $0.25 \mathrm{~mm}$ ) phenocrysts, large amphibole crystals (approx. $1.5 \mathrm{~mm}$ ), rare biotite and accessory minerals. B: Amphibole of the Damjan intrusion showing a $10 \mu \mathrm{m}$ thick rim of different chemical composition. 
Table

Major, trace and REE element composition of whole rock samples of the Buchim-Damjan-Borov Dol ore district, including the detecting limits for their trace and REE elements.

\begin{tabular}{|c|c|c|c|c|c|c|c|c|c|c|c|c|c|c|c|c|c|c|c|c|c|c|c|c|}
\hline \multirow[t]{2}{*}{$\begin{array}{l}\text { Sample } \\
\text { location }\end{array}$} & $\begin{array}{l}\text { Black } \\
\text { Hill }\end{array}$ & 278-D-8 & 278-D-1 & 278-D-4 & 278-D-5 & 029-1 & $029-3$ & $029-5$ & 059-3 & 059-1 & 268-1-A & $238-3$ & $238-4$ & $228-1$ & $248-2$ & $248-1$ & 056-3 & $056-5$ & $\mathrm{C} 1$ & V1 & $046-10$ & $029-7$ & 046-15 & LOD \\
\hline & $\begin{array}{l}\text { Black } \\
\text { Hill }\end{array}$ & Damjan & Damjan & Damjan & Damjan & $\begin{array}{l}\text { Borov } \\
\text { Dol }\end{array}$ & $\begin{array}{l}\text { Borov } \\
\text { Dol }\end{array}$ & $\begin{array}{l}\text { Borov } \\
\text { Dol }\end{array}$ & Bunardzik & Bunardzik & Central & Vrsnik & Vrsnik. & Vrsnik & Vrsnik & Vrsnik & Central & Central & $\begin{array}{l}\text { Central } \\
\text { enclave }\end{array}$ & $\begin{array}{l}\text { Vrsnik } \\
\text { enclave }\end{array}$ & $\begin{array}{l}\text { Borov } \\
\text { Dol }\end{array}$ & $\begin{array}{l}\text { Borov } \\
\text { Dol }\end{array}$ & $\begin{array}{l}\text { Borov } \\
\text { Dol }\end{array}$ & \\
\hline $\mathrm{SiO}_{2}$ & 67.98 & 57.95 & 60.20 & 59.19 & 60.64 & 61.93 & 61.87 & 59.56 & 62.55 & 60.06 & 61.59 & 59.48 & 60.70 & 60.11 & 61.24 & 63.10 & 62.79 & 58.89 & 50.71 & 58.14 & 58.03 & 52.19 & 58.24 & \\
\hline $\mathrm{TiO}_{2}$ & 0.29 & 0.52 & 0.54 & 0.54 & 0.54 & 0.49 & 0.54 & 0.58 & 0.51 & 0.52 & 0.52 & 0.44 & 0.45 & 0.44 & 0.56 & 0.48 & 0.42 & 0.49 & 0.75 & 0.57 & 0.46 & 0.39 & 0.70 & \\
\hline $\mathrm{Al}_{2} \mathrm{O}_{3}$ & 16.89 & 15.94 & 16.23 & 16.50 & 16.72 & 16.89 & 16.32 & 16.40 & 16.87 & 16.30 & 15.57 & 15.39 & 15.76 & 15.05 & 16.74 & 16.39 & 15.79 & 15.15 & 13.53 & 17.00 & 8.93 & 6.85 & 8.07 & \\
\hline $\mathrm{Fe}_{2} \mathrm{O}_{3}$ & 2.10 & 3.14 & 5.24 & 2.97 & 4.97 & 4.76 & 6.58 & 5.48 & 5.06 & 5.20 & 5.22 & 6.41 & 4.61 & 7.04 & 6.29 & 4.92 & 4.72 & 7.31 & 15.14 & 8.57 & 6.84 & 8.04 & 2.88 & \\
\hline $\mathrm{MnO}$ & 0.01 & 0.11 & 0.11 & 0.09 & 0.10 & 0.21 & 0.05 & 0.08 & 0.07 & 0.08 & 0.07 & 0.15 & 0.07 & 0.16 & 0.05 & 0.08 & 0.03 & 0.07 & 0.11 & 0.09 & 0.19 & 0.19 & 0.28 & \\
\hline MgO & 0.15 & 2.04 & 2.23 & 1.85 & 2.61 & 1.95 & 1.68 & 1.95 & 1.70 & 1.59 & 2.18 & 1.52 & 1.54 & 1.67 & 2.21 & 1.78 & 1.80 & 2.09 & 2.94 & 2.03 & 11.19 & 22.01 & 1.13 & \\
\hline $\mathrm{CaO}$ & 0.68 & 8.36 & 5.26 & 7.77 & 5.30 & 4.14 & 2.93 & 5.26 & 4.00 & 3.74 & 4.28 & 3.44 & 4.46 & 1.71 & 2.48 & 3.84 & 2.91 & 4.55 & 6.30 & 2.76 & 7.21 & 5.05 & 13.57 & \\
\hline $\mathrm{Na}_{2} \mathrm{O}$ & 4.57 & 6.90 & 4.41 & 4.17 & 4.24 & 3.95 & 3.61 & 4.14 & 4.16 & 3.98 & 3.68 & 3.09 & 3.73 & 2.58 & 3.94 & 3.67 & 3.32 & 3.51 & 5.21 & 6.67 & 2.92 & 0.40 & 1.38 & \\
\hline $\mathrm{K}_{2} \mathrm{O}$ & 5.79 & 0.51 & 3.61 & 3.93 & 3.71 & 3.18 & 4.90 & 3.72 & 3.90 & 3.81 & 4.56 & 5.89 & 4.57 & 5.58 & 4.30 & 4.65 & 5.53 & 5.44 & 1.50 & 1.41 & 1.54 & 2.62 & 1.54 & \\
\hline $\mathrm{P}_{2} \mathrm{O}_{5}$ & 0.14 & 0.28 & 0.30 & 0.30 & 0.30 & 0.38 & 0.30 & 0.32 & 0.32 & 0.32 & 0.29 & 0.27 & 0.28 & 0.27 & 0.34 & 0.28 & 0.24 & 0.30 & 0.36 & 0.38 & 0.07 & 0.05 & 0.09 & \\
\hline Total & 99.63 & 99.99 & 99.56 & 99.91 & 99.96 & 99.59 & 99.84 & 99.88 & 99.90 & 100.03 & 99.92 & 100.06 & 99.80 & 99.85 & 99.66 & 99.84 & 99.95 & 99.82 & 99.77 & 99.89 & 100.23 & 100.34 & 100.04 & \\
\hline Sc & 4.5 & 13.3 & 14.3 & 14.6 & 14.2 & 9.6 & 13.5 & 14.0 & 12.5 & 12.6 & 12.3 & 9.0 & 8.7 & 8.1 & 13.2 & 9.8 & 9.2 & 12.9 & 26.7 & 9.2 & 20.1 & 17.9 & 12.6 & 1.2 \\
\hline $\mathrm{V}$ & 91.1 & 182 & 194 & 199 & 191 & 152 & 191 & 201 & 184 & 183 & 188 & 153 & 155 & 143 & 206 & 165 & 144 & 174 & 316 & 243 & 116 & 127 & 79.4 & 1 \\
\hline $\mathrm{Cr}$ & 19.2 & 24.1 & 16.0 & 19.5 & 21.2 & 16.1 & 24.0 & 17.9 & 14.3 & 18.8 & 27.6 & 15.9 & 17.7 & 18.9 & 23.1 & 18.2 & 22.8 & 24.5 & 73.3 & & 1772.8 & 1871.9 & 65.0 & 10 \\
\hline $\mathrm{Mn}$ & 115 & 843 & 853 & 748 & 773 & 1694 & 383 & 643 & 516 & 622 & 553 & 1167 & 593 & 1321 & 446 & 633 & 240 & 503 & 833 & 678 & 1443 & 1461 & 2003 & 2 \\
\hline $\mathrm{Co}_{0}$ & 2.6 & 8.2 & 9.7 & 8.4 & 11.0 & 9.7 & 9.7 & 9.6 & 10.8 & 11.0 & 13.3 & 10.3 & 11.0 & 7.9 & 14.1 & 8.8 & 11.3 & 8.6 & 13.7 & 9.2 & 87.3 & 54.7 & 6.4 & 0.5 \\
\hline $\mathrm{Ni}$ & 8.4 & 8.5 & 8.4 & 13.8 & 13.4 & 8.2 & 17.4 & 9.5 & 16.3 & 13.9 & 11.9 & 9.9 & 12.2 & 11.9 & 21.6 & 9.2 & & 28.6 & 12.3 & 16.0 & 1110.0 & 1257.9 & 33.1 & 5 \\
\hline $\mathrm{Cu}$ & 19.6 & 9.5 & 39.9 & 17.1 & 125 & 7.4 & 2001 & 70.3 & 223 & 168 & 527.2 & 154 & 72.8 & 135 & 641 & 96.2 & 391 & 74.0 & 296 & 38.0 & 5.2 & 181 & 10.3 & 2 \\
\hline $\mathrm{Zn}$ & 28.7 & 308.2 & 44.3 & 34.6 & 36.6 & 175.1 & 41.2 & 34.8 & 48.7 & 45.4 & 29.1 & 71.9 & 38.2 & 32.8 & 40.6 & 35.8 & 27.2 & 27.7 & 41.4 & 50.8 & 42.3 & 65.2 & 33.1 & 3 \\
\hline $\mathrm{Ga}$ & 25.4 & 18.7 & 20.3 & 20.4 & 19.4 & 21.4 & 20.9 & 20.2 & 19.8 & 19.4 & 20.1 & 20.4 & 20.6 & 20.4 & 22.2 & 19.9 & 20.0 & 19.4 & 24.4 & 26.3 & 9.5 & 7.9 & 8.3 & 0.7 \\
\hline $\mathrm{Ge}$ & $<$ b.d.l & 5.0 & 4.3 & $<$ b.d.l. & 5.7 & <b.d.l & 4.8 & 4.0 & $<$ b.d.l & 5.2 & <b.d.l & $<$ b.d.l & $<$ b.d.l & 3.5 & 4.1 & $<$ b.d.l & $<$ b.d.l & 7.3 & 6.9 & 7.3 & <b.d.l & 7.3 & $<$ b.d.l & 3 \\
\hline As & 10.6 & 9.2 & 3.1 & 2.8 & 2.0 & 3.7 & 1.8 & 3.2 & 2.5 & 5.3 & 16.7 & 10.5 & 5.0 & 21.7 & 9.4 & 9.8 & 64.3 & 10.4 & 36.7 & 17.2 & 8.1 & $<$ b.d.l & 7.7 & 1.5 \\
\hline $\mathrm{Rb}$ & 270.40 & 25.0 & 91.4 & 80.0 & 78.8 & 102 & 86.2 & 88.3 & 113 & 121 & 118 & 242 & 151 & 221 & 133 & 165 & 119 & 110 & 44.3 & 49.9 & 33.4 & 149 & 50.5 & 0.3 \\
\hline $\mathrm{Sr}$ & 1301 & 1613 & 1583 & 1900 & 1618 & 1728 & 1677 & 1858 & 1819 & 1756 & 1457 & 573 & 1486 & 324 & 1607 & 824 & 1182 & 1252 & 785 & 1484 & 59.5 & 82.6 & 99.4 & 0.2 \\
\hline Y & 15.5 & 22.0 & 24.4 & 25.6 & 23.3 & 24.7 & 19.2 & 24.4 & 25.7 & 24.3 & 24.2 & 22.9 & 23.6 & 28.4 & 30.2 & 25.6 & 23.4 & 27.7 & 37.8 & 39.6 & 15.2 & 12.4 & 27.2 & 0.2 \\
\hline
\end{tabular}


Table 3 (continued)

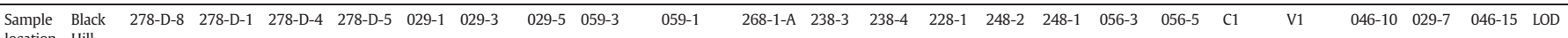
location Hil

Black Damjan Damjan Damjan Damjan Borov Borov Borov Bunardzik Bunardzik Central Vrsnik Vrsnik. Vrsnik Vrsnik Vrsnik Central Central Central Vrsnik Borov Borov Borov

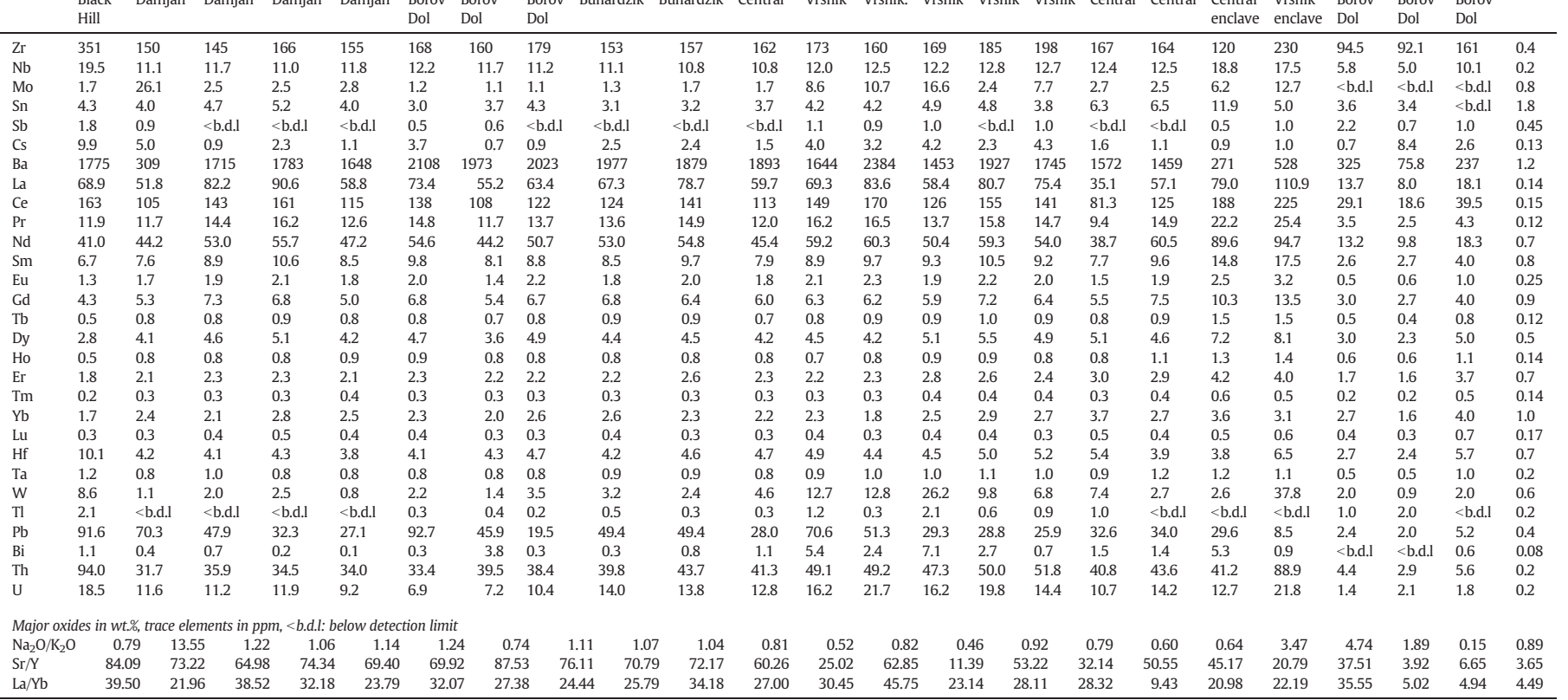



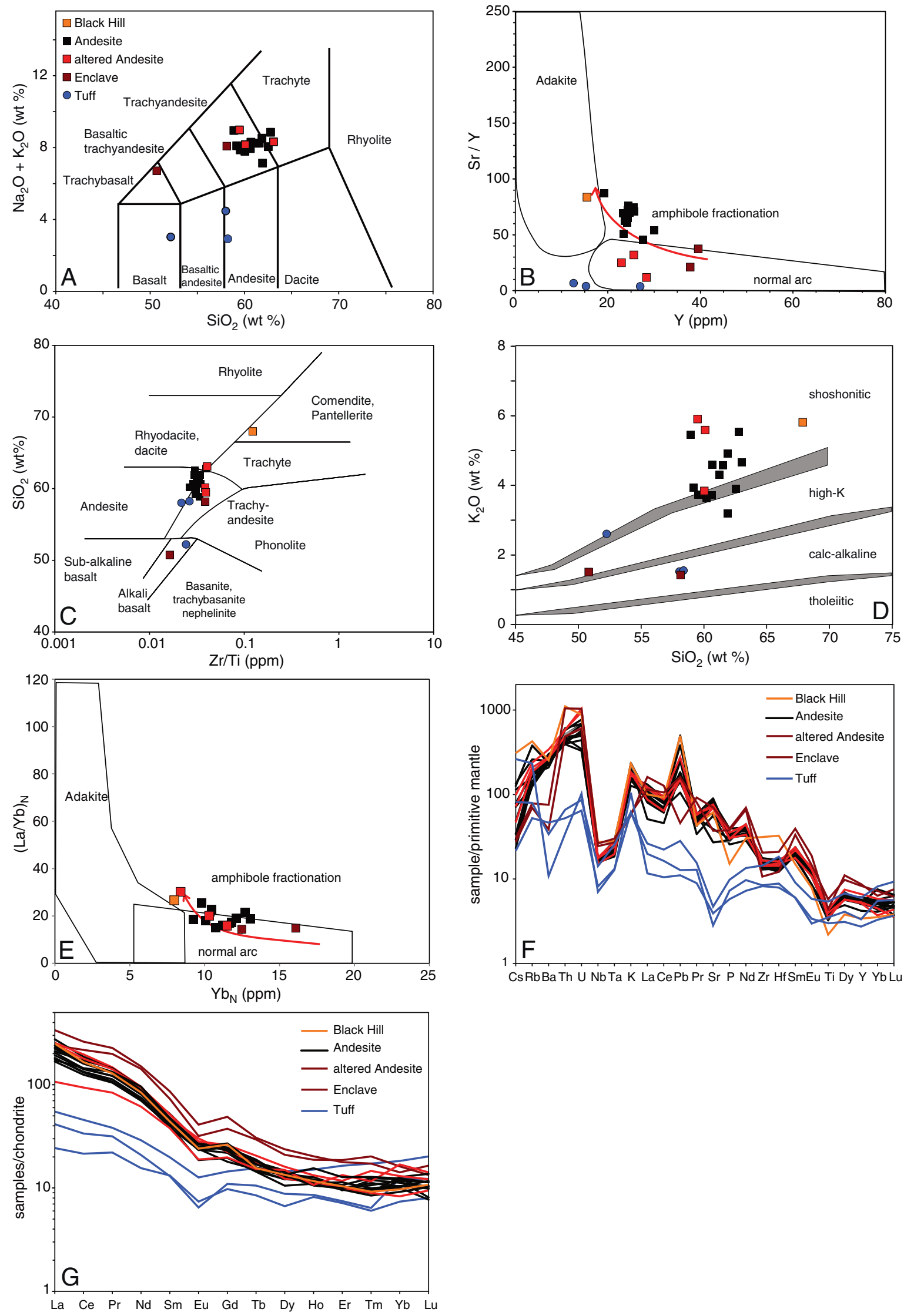

Fig. 6. A: TAS diagram for the classification of volcanic rocks (Le Maitre et al., 1989). B: Sr/Y vs. Y diagram modified after Castillo et al., 1999 and Defant and Drummond (1990). The red line illustrates a possible amphibole fractionation line from a primitive magma to an evolved magma. $\mathrm{C}: \mathrm{SiO}_{2}$ (wt \%) vs. $\mathrm{Zr} / \mathrm{Ti}$ (ppm) trace element classification for subvolcanic/volcanic rocks (Winchester and Floyd, 1977). D: $\mathrm{K}_{2} \mathrm{O}$ (wt \%) vs. $\mathrm{SiO}_{2}$ (wt \%) classification diagram (Rickwood, 1989). E: La/ $\mathrm{Yb}_{\mathrm{n}} \mathrm{Vs}$. Yb $\mathrm{b}_{\mathrm{n}}$ discrimination diagram between adakitic and normal arc rocks. F: Primitive mantle-normalized multi-element pattern. G: Chondrite normalized REE patterns. C1 chondrite and primitive mantle values after Sun and McDonough, 1989. 


\subsubsection{Enclaves and tuffs}

Two mafic microgranular enclaves were analyzed (C1, V1; Table 3): one from the Central intrusion and the other from the Vrsnik intrusion. The size of the enclaves ranges from 1 to $10 \mathrm{~cm}$, the smaller ones are more common. The analyzed enclaves were partially affected by the hydrothermal alteration. Especially the one of the Vrsnik intrusion underwent alteration of probably propylitic or even phyllic-argillic exchange reactions. In contrast to the Vrsnik enclave, the enclave of the Central intrusion was altered to a very low degree. Both show lower $\mathrm{SiO}_{2}$ contents than the other samples. Additionally, the enclaves show distinctly higher $\mathrm{FeO}_{\text {tot }}, \mathrm{Na}_{2} \mathrm{O}$ and $\mathrm{Y}$ concentrations as well as lower $\mathrm{K}_{2} \mathrm{O}$ and $\mathrm{Sr}$ concentration than the intrusives. The three tuff samples were collected in the Borov Dol area (Fig. 2). On the Serbian Kavadarci map (Hristov et al., 1973) they are considered to be older than the intrusion (Fig. 2B). All of them have slightly different mineralogies, but all show a fine-grained structure (hypohyaline to hypocrystalline, Table 2). Their geochemical distribution patterns are shown in the multi-element normalized and REE diagrams (Figs. $6 \mathrm{~F}$, $\mathrm{G}$ ); their geochemical composition is different from the intrusive rocks of Buchim, Damjan and Borov Dol, e.g. lower content of the REE, including a negative Eu anomaly, and lower concentration in most trace elements.

\subsubsection{Sr and Nd isotopes}

Whole rock $\mathrm{Sr}$ and $\mathrm{Nd}$ isotopic compositions are presented in Figs. 7A and B. The proposed mixing curve is in agreement with the data from Pe-Piper and Piper (2001). Only a few isotopic analyses are available for young magmatic rocks of this region (intrusive rocks from F.Y.R. of Macedonia, Serbia and Bulgaria; Yanev et al., 2008; Prelević et al., 2005; Marchev et al., 2004; Cvetković et al., 2004) which are plotted with our data on Fig. 7A and B (Table 4).

\section{4. $U-P b$ zircon dating}

The shape and the color of the zircons are similar in all samples. They are all beige to colorless and medium to long prismatic (Fig. 8A-C). Backscattered-electron and cathodoluminescence (BSE and CL) images show that the zircons have a fine oscillatory zoning pattern (Fig. 8) and that none of the zircons contain older cores. Some of them show mineral inclusions (visible with BSE) and fluid inclusions (detected on the laser signal). The $\mathrm{U}-\mathrm{Pb}$ ages were calculated using the Glitter software (van Achterbergh et al., 2001) and all individual analyses are illustrated in Fig. 9. The ages of the dated intrusions range from $24.04 \pm 0.77$ to $24.51 \pm 0.89 \mathrm{Ma}$ (Fig. 9). Older ages were obtained from two zircons, one in sample 029-1 and the other in sample 029-5. The majority of the analyzed zircons gave concordant ages. The ages show a slight amount of scatter between the samples but the ages overlap within error.

\subsection{REE/Hf in zircon}

All dated zircon samples were analyzed for the trace/REE element contents and the Hf isotopic characteristics (Tables 6, 7). The zircon grains of all geochronologically investigated samples yielded similar REE patterns. They show the common characteristic magmatic pattern with a steep enrichment in HREE (Fig. 8; Belousova et al., 2002;
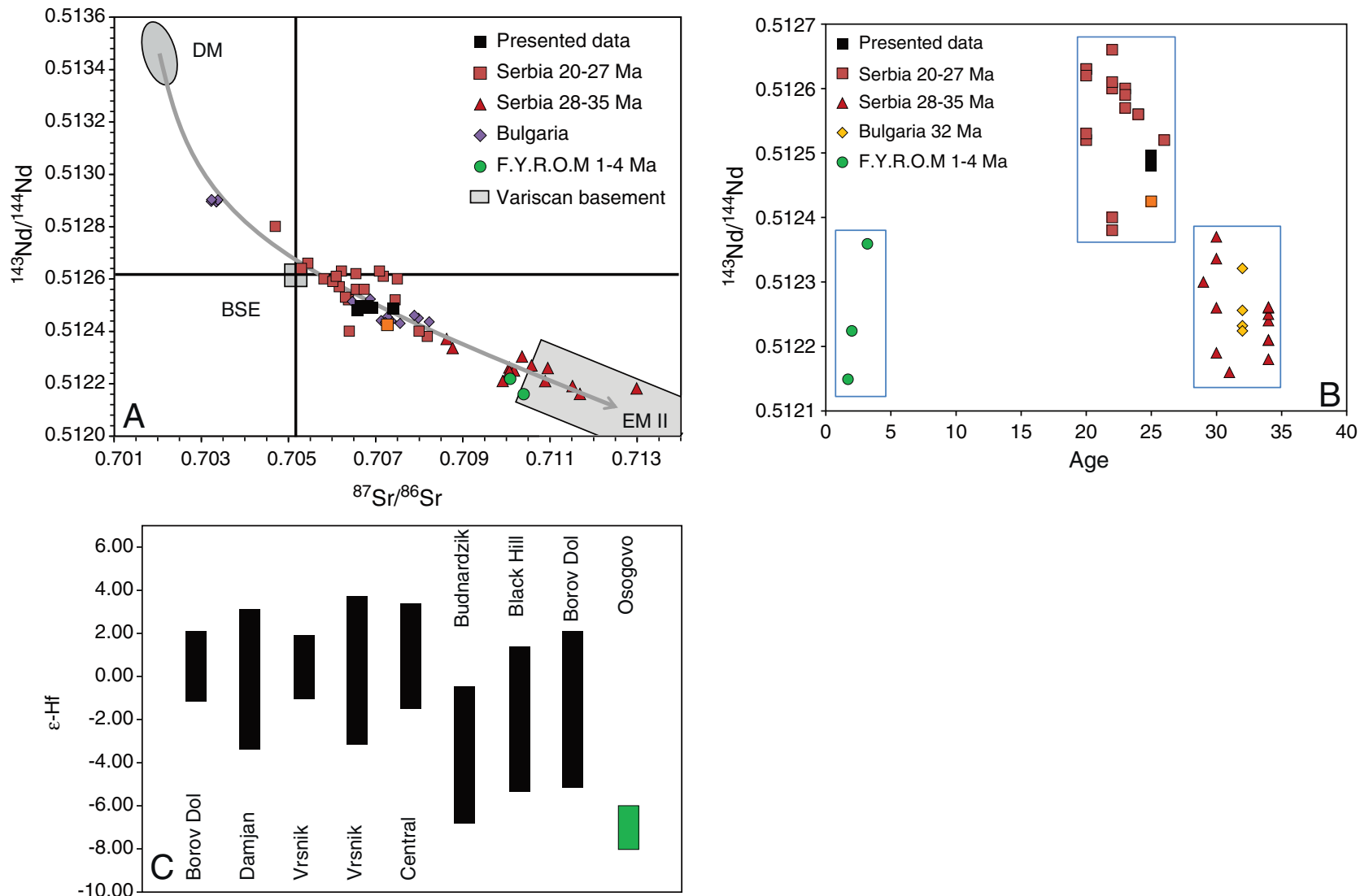

Fig. 7. A: Initial ${ }^{87} \mathrm{Sr} /{ }^{86} \mathrm{Sr}$ vs. initial ${ }^{143} \mathrm{Nd} /{ }^{144} \mathrm{Nd}$ correlation diagram. The samples from Serbia and Bulgaria represent magmatic rocks with an age between 20 and $35 \mathrm{Ma}$. A hyperbolic mixing curve for different ratios of $(\mathrm{Sr} / \mathrm{Nd})_{\mathrm{EMII}} /(\mathrm{Sr} / \mathrm{Nd})_{\mathrm{DM}}$ shows mixing between a depleted mantle (DM) and an enriched mantle (EMII) source. It illustrates that the measured $\mathrm{Sr}-\mathrm{Nd}$ isotopic ratio is a result of magma mixing or crustal contamination (Cvetković et al., 2004; Depaolo and Wasserburg, 1979; Graf, 2001; Marchev et al., 2004; Prelević et al., 2005; Rollinson, 1993; Yanev et al., 2008). B: ${ }^{143} \mathrm{Nd} /{ }^{144} \mathrm{Nd}$ vs. time plot (age in Ma). It shows the evolution of Nd isotope ratios during the last $35 \mathrm{Ma}$ in Macedonia and Serbia (Cvetković et al., 2004; Graf, 2001; Marchev et al., 2004; Prelević et al., 2005; Yanev et al., 2008). C: $\varepsilon$-Hf zircon values of the Buchim-Damjan-Borov Dol intrusive rocks, in green the 31 Ma old intrusion of the Osogovo (Graf, 2001). 
Table 4

$\mathrm{Rb}-\mathrm{Sr}$ and Sm-Nd data for magmatic rocks from the Buchim-Damjan-Borov Dol ore district.

\begin{tabular}{|c|c|c|c|c|c|c|c|c|c|c|c|c|c|}
\hline Sample & $\mathrm{Rb}$ & $\mathrm{Sr}$ & ${ }^{87} \mathrm{Rb} /{ }^{86} \mathrm{Sr}$ & ${ }^{87} \mathrm{Sr} /{ }^{86} \mathrm{Sr}$ & $2 \sigma$ error & at $24 \mathrm{Ma}$ & $\mathrm{Sm}$ & $\mathrm{Nd}$ & ${ }^{147} \mathrm{Sm} /{ }^{144} \mathrm{Nd}$ & ${ }^{143} \mathrm{Nd} /{ }^{144} \mathrm{Nd}$ & $2 \sigma$ error & ${ }^{143} \mathrm{Nd} /{ }^{144} \mathrm{Nd} \mathrm{T-24} \mathrm{Ma}$ & $\varepsilon-\mathrm{Nd} \mathrm{T}-24 \mathrm{Ma}$ \\
\hline 268-1-A & 117.9 & 1457.2 & 0.2284 & 0.70700 & 0.00001 & 0.70693 & 7.87 & 45.41 & 0.1088 & 0.512506 & 0.000011 & 0.512489 & -2.31 \\
\hline 278-D-1 & 91.4 & 1582.9 & 0.1630 & 0.70672 & 0.00001 & 0.70666 & 8.95 & 53.01 & 0.1059 & 0.512512 & 0.000003 & 0.512495 & -2.18 \\
\hline $248-2$ & 132.7 & 1607.2 & 0.2331 & 0.70697 & 0.00001 & 0.70689 & 10.51 & 59.28 & 0.1113 & 0.512506 & 0.000021 & 0.512489 & -2.31 \\
\hline 059-1 & 165.4 & 823.6 & 0.5668 & 0.70686 & 0.00002 & 0.70666 & 9.23 & 53.95 & 0.1074 & 0.512506 & 0.000005 & 0.512489 & -2.30 \\
\hline $029-5$ & 88.3 & 1858.1 & 0.1342 & 0.70686 & 0.00002 & 0.70681 & 8.80 & 50.65 & 0.1090 & 0.512514 & 0.000004 & 0.512497 & -2.15 \\
\hline 029-1 & 101.7 & 1727.7 & 0.1662 & 0.70664 & 0.00001 & 0.70658 & 9.81 & 54.62 & 0.1127 & 0.512498 & 0.000007 & 0.512480 & -2.47 \\
\hline $238-3$ & 241.9 & 573.4 & 1.1906 & 0.70781 & 0.00001 & 0.70741 & 8.91 & 59.23 & 0.0944 & 0.512502 & 0.000012 & 0.512487 & -2.34 \\
\hline Black Hill & 270.4 & 1301.4 & 0.5865 & 0.70747 & 0.00002 & 0.70727 & 6.66 & 41.00 & 0.1020 & 0.512441 & 0.000022 & 0.512425 & -3.55 \\
\hline
\end{tabular}

Hoskin and Ireland, 2000), a significant positive Ce anomaly and a weak negative Eu anomaly. The negative Eu anomaly of the zircon grains is similar to the whole rock patterns (Fig. 6G). The measured $\varepsilon$-Hf values of the zircons are listed in Table 7 and the data are plotted in Fig. 7C. The $\varepsilon$-Hf values of all analyzed zircon grains range between -6.83 and 3.77. There are groups (Bunardzik, Black Hill and Borov Dol) with stronger negative $\varepsilon$-Hf values, starting at -6.8 and a second group (Borol Dol, Damjan, Vrsnik, Central) with less negative values around -3.2; two samples of Borov Dol represent different localities; sample 029-5 is taken from the porphyry region of Borov Dol (Fig. 2) and 029-1, the second sample, is taken from outer parts of the Borov Dol region (Fig. 2; $200 \mathrm{~m} \mathrm{SW}$ of Borov Dol).

\section{Discussion}

\subsection{Magma evolution}

Fig. 6 A shows $\mathrm{SiO}_{2}$ wt.\% vs. $\mathrm{K}_{2} \mathrm{O}$ wt.\% and the $\mathrm{Na}_{2} \mathrm{O} / \mathrm{K}_{2} \mathrm{O}$ ratios are available in Table 3. Two rock groups are distinguished: one with a typical calc-alkaline character ranging to shoshonitic characteristics with a steady increase in $\mathrm{K}_{2} \mathrm{O}$ and increasing $\mathrm{SiO}_{2}$ concentration $\left(\mathrm{Na}_{2} \mathrm{O} / \mathrm{K}_{2} \mathrm{O}\right.$
0.5-4.7) and the other displaying low $\mathrm{K}_{2} \mathrm{O}$ contents $\left(\mathrm{Na}_{2} \mathrm{O} / \mathrm{K}_{2} \mathrm{O} 0.2-\right.$ 1.9; Table 3) with increasing $\mathrm{SiO}_{2}$ concentrations. REE and trace element patterns normalized to $\mathrm{CI}$-chondrite and primitive mantle are presented in Figs. 6F, G. Enrichment in light REE (LREE) and relatively flat heavy REE (HREE) patterns is a general feature of all samples of the Buchim region. All samples, except the three tuff samples, show E-MORB-like patterns, a typical phenomenon of subduction zone magmas (Fig. 6G, $\mathrm{E}, \mathrm{F}$ ). Large ion lithophile elements (LILE) such as $\mathrm{U}, \mathrm{Th}, \mathrm{Pb}$ are enriched; the high field strength elements (HFSE) like Zr, Hf, Nb and Ta display negative anomalies. These patterns are remarkably similar for all rocks from the Buchim area, except the tuffs with lower concentrations. All samples show slight negative Eu anomalies.

The high $\mathrm{Sr} / \mathrm{Y}$ and La/ $\mathrm{Yb}$ ratios (Table 3) may be an indicator for a high pressure and/or strongly hydrous fractionation (Kolb et al., 2012). Microprobe analyses on amphibole inclusions within plagioclase show conditions which are linked to high-pressure. This is supported by the two feldspar thermometry (Blundy and Holland, 1990; Lehmann et al., 2012; Schmidt, 1992). Sr is enriched in the melt due to a suppression of plagioclase crystallization during early magma evolution (Rohrlach and Loucks, 2005) and a high-pressure mineral paragenesis is observed. The term "adakite" was introduced originally for volcanic
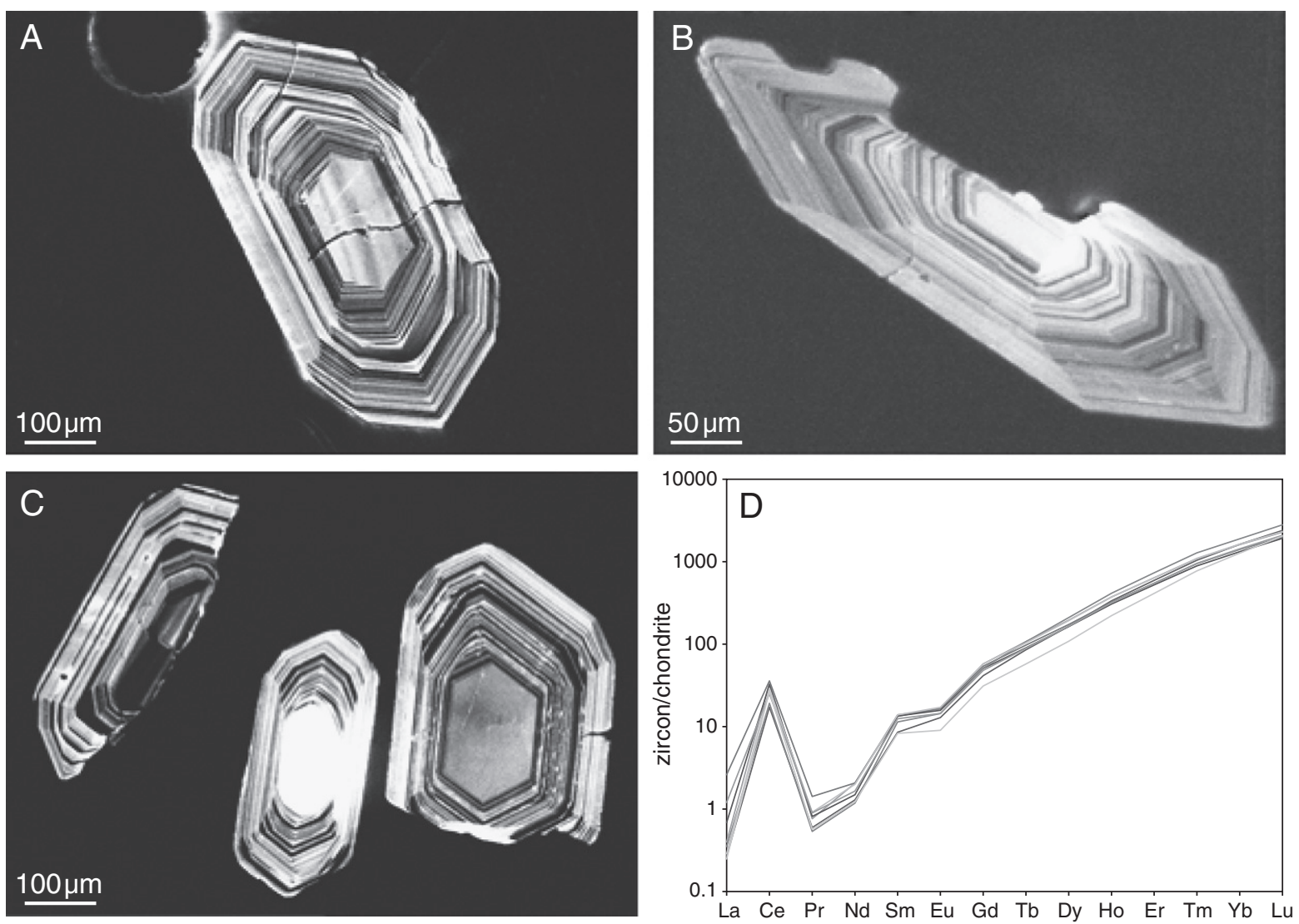

Fig. 8. Zircon cathodoluminescence (Cl) images of zircons from the samples: A) 059-1, B) 029-5 and C) 248-2. (D) The REE distribution of all samples plotted together. 

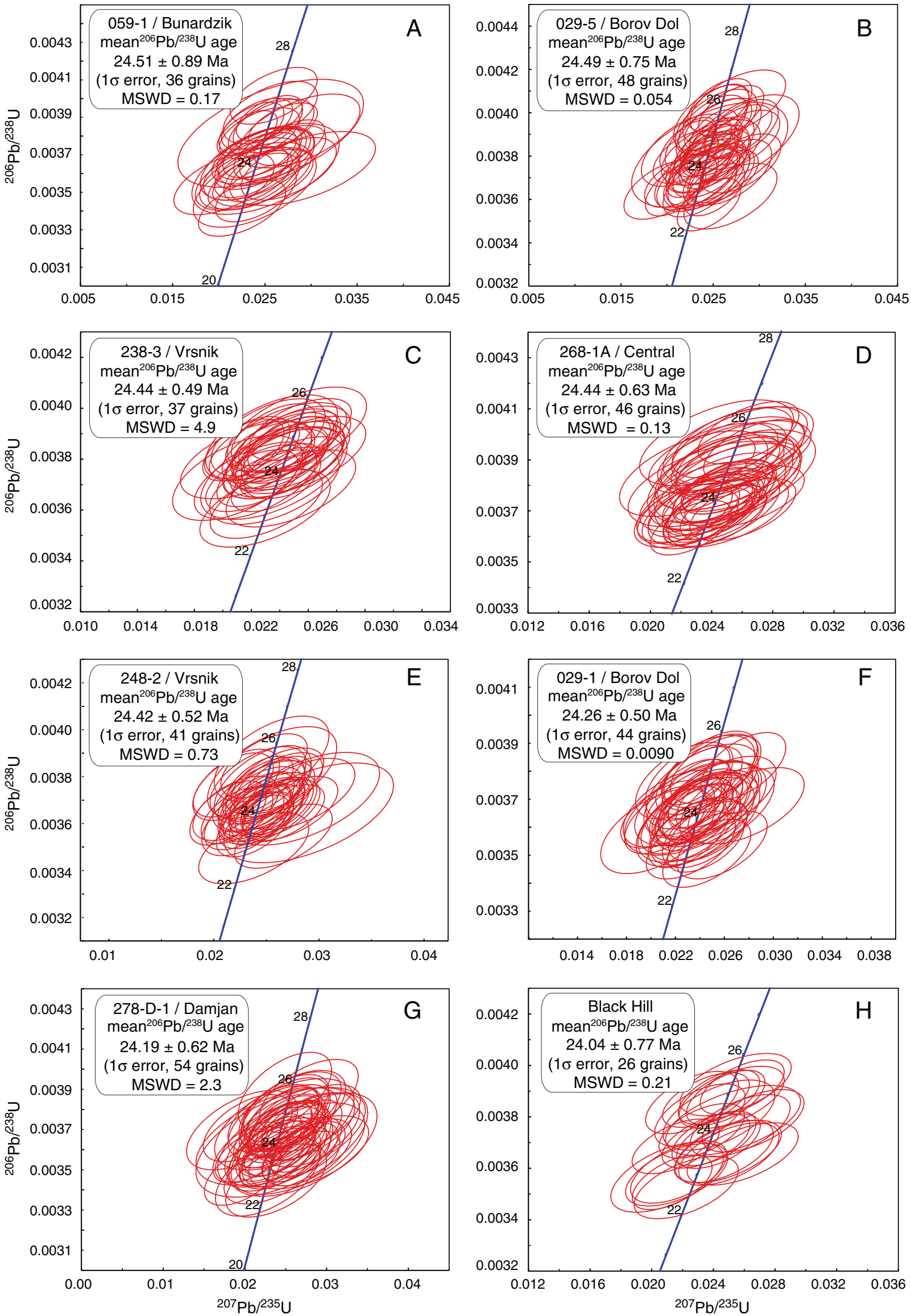

Fig. 9. U-Pb concordia diagrams for single grain zircon analyses of the samples: A) 059-1, Bunardzik; B) 029-5, Borov Dol; C) 029-1, Borov Dol; D) 268-1A, Central; E) 238-3, Vtsnik; F) 278-D-1, Damjan; G) 248-2, Vrsnik; H) Black Hill. 
Table 6

REE values of the selected zircon-grains.

\begin{tabular}{lcrrrrrrr}
\hline Sample & $278-\mathrm{D}-1$ & $248-2$ & $238-3$ & $268-1 \mathrm{~A}$ & $029-1$ & $059-1$ & $029-5$ & Black Hill \\
\hline La & 0.1 & 0.1 & 0.9 & 0.2 & 0.1 & 0.1 & 0.4 & 0.1 \\
$\mathrm{Ce}$ & 14.9 & 29.2 & 31.0 & 27.9 & 16.5 & 25.0 & 21.8 & 23.1 \\
$\mathrm{Pr}$ & 0.1 & 0.1 & 0.2 & 0.1 & 0.1 & 0.1 & 0.1 & 0.1 \\
$\mathrm{Nd}$ & 0.8 & 1.3 & 1.3 & 0.9 & 0.7 & 1.3 & 1.0 & 0.8 \\
$\mathrm{Sm}$ & 1.7 & 2.8 & 2.7 & 2.7 & 2.3 & 2.8 & 2.5 & 1.7 \\
$\mathrm{Eu}$ & 1.0 & 1.3 & 1.3 & 1.2 & 1.1 & 1.3 & 1.1 & 0.7 \\
$\mathrm{Gd}$ & 11.4 & 15.8 & 14.9 & 14.0 & 14.1 & 15.9 & 13.3 & 8.6 \\
$\mathrm{~Tb}$ & 4.3 & 5.4 & 4.9 & 4.5 & 5.3 & 5.2 & 4.4 & 2.9 \\
$\mathrm{Dy}$ & 56.5 & 66.9 & 59.2 & 56.0 & 71.8 & 65.9 & 56.4 & 37.1 \\
$\mathrm{Ho}$ & 23.4 & 26.1 & 22.6 & 21.4 & 28.9 & 26.1 & 22.2 & 15.5 \\
Er & 133 & 143 & 123 & 118 & 165 & 143 & 123 & 92.7 \\
$\mathrm{Tm}$ & 31.2 & 32.4 & 28.3 & 26.6 & 38.3 & 32.9 & 28.6 & 23.1 \\
Yb & 356 & 353 & 310 & 290 & 416 & 358 & 315 & 279 \\
$\mathrm{Lu}$ & 81.2 & 77.2 & 67.2 & 65.1 & 95.0 & 78.3 & 70.8 & 69.2 \\
\hline
\end{tabular}

All values are in ppm.

and plutonic rocks with intermediate to felsic composition with the following parameters: $\mathrm{SiO}_{2}>56$ wt.\%, $\mathrm{Al}_{2} \mathrm{O}_{3}>15$ wt.\%, $\mathrm{MgO}>3$ wt.\%, $\mathrm{La} / \mathrm{Yb}>20, \mathrm{Sr} / \mathrm{Y}>20$ and $\mathrm{Y}<18$ ppm (Defant and Drummond, 1990). Additionally, Martin et al. (2005) identified two adakite types based on their $\mathrm{SiO}_{2}$ contents: high-SiO${ }_{2}$ adakites (HSA; $\mathrm{SiO}_{2}>60$ wt.\%) and low- $\mathrm{SiO}_{2}$ adakites ( $\mathrm{LSA} ; \mathrm{SiO}_{2}<60$ wt.\%). There is a general agreement that garnet and/or amphibole fractionation is involved in the petrogenesis of these rocks causing depletion of HREE and Y. All investigated rock samples, except the tuffs, all fulfill the criteria by Defant and Drummond (1990), but a detailed interpretation of the Sr/Y vs. Y and La/Yb vs. Yb diagrams (Fig. 6B, E) is difficult, because the observed distribution form distinct adakite-like and normal arc trends (Fig. 6B, E). Several samples (Table 3) show characteristic $\mathrm{Sr} / \mathrm{Y}$ ratios $>20$ together with an enrichment of $\mathrm{Y}$; the $\mathrm{Y}$ and $\mathrm{Yb}$ enrichment is classified as being of normal arc type, starting with an amphibole fractionation (Jahn et al., 1981) and a plagioclase fraction (Fig. 6F, G). However, the REE distribution (Fig. 6G) only suggests a small amount of plagioclase fractionation for the enclaves which have probably originated from the same magma in an earlier crystallization phase.

In the lowest part of the magma chamber, the magma evolution starts with fractional crystallization of the amphibole, which is observed as a slight "hockey stick" pattern in the REE-plot (Fig. 6G, whole rock data). The hockey stick pattern is characterized by an enrichment of the light REE and a depletion of the heavy REE. In addition, the REE plot shows a weak negative Eu anomaly. This indicates that there was weak plagioclase fractionation. The zircons show a strong positive Ce anomaly $\left(\mathrm{Ce} / \mathrm{Ce}^{*}=200\right)$ and a weak negative Eu anomaly $\left(\mathrm{Eu} / \mathrm{Eu}^{*}=\right.$ $0.2)$. The magnitude of the anomalies are expressed as $\mathrm{Ce} / \mathrm{Ce}^{*}$ and $\mathrm{Eu} / \mathrm{Eu}^{*}$ ratios where $\mathrm{Ce}^{*}$ and $\mathrm{Eu}^{*}$ are the expected values for a smooth normalized pattern. The ratios are calculated according to Hoskin and Schaltegger (2003), the anomalies were calculated in this manner; for example Ce/Ce*: $\mathrm{Ce}_{\mathrm{n}} / \sqrt{\mathrm{La}_{\mathrm{n}}} * \operatorname{Pr}_{\mathrm{n}}$. The Ce and Eu anomalies in the zircon give information about the oxidation state of the melt. Ce can be present as $4^{+}$and $3^{+}$in the melt, depending on the oxidation state of the melt. Because the $4^{+}$cations are more soluble in the zircons, the Ce anomaly in the zircon is a function of the oxygen fugacity (Belousova et al., 2002; Hoskin and Schaltegger, 2003). Ce/Ce* ratios which are greater than one indicate an oxidizing environment. Eu can have a divalent or trivalent charge. Therefore the magnitude of the Eu-anomaly is redox sensitive. $\mathrm{Eu} / \mathrm{Eu}^{*}$ ratios, which are smaller than one, indicate reducing conditions. A corresponding Eu and Ce anomaly should not be possible. In this case, the magma would be both oxidizing as well as reducing. The paradox is explained by an earlier crystallization of plagioclase that had depleted the magma in Eu (Hoskin and Schaltegger, 2003; Snyder et al., 1993). This leads to the conclusion that during zircon crystallization the magma was in an oxidizing state. The results of a semi-quantitative microprobe analyses suggests, that there are three different crystallization stages in the middle to upper continental crust (Lehmann et al.,
2012). The deepest was probably located at a maximal depth of around $20 \mathrm{~km}$ (5.3 kbar) at which the upper crust shows $\mathrm{Sr}-\mathrm{Nd}$ affinities (Zindler and Hart, 1986) to the enriched mantle II (EM II). At a second and shallower level of crystallization, measurements of amphibole rims from the Buchim central body suggest a pressure of 3.2-3.3 kbar, which denotes a crystallization depth of about $12 \mathrm{~km}$. A last amphibole crystallization sequence occurred at about $1.5 \mathrm{kbar}$ (5.8 km; Lehmann et al., 2012).

Magma mingling and mafic enclaves (Fig. $4 \mathrm{E}$ and $\mathrm{F}$ ) have been observed during the fieldwork and the zoned phenocrysts (plagioclase, sanidine, allanite, amphibole) provide clear evidence for magma mixing within a deeper magma chamber (Browne et al., 2006; Davidson et al., 2007; Ruprecht and Woerner, 2007; Smith et al., 2009; Vernon et al., 1988). Three magmas with mingling structures are found in the Vrsnik intrusions (Fig. 4E): (1) foliated fine grained granodiorite-porphyry (arrow 1); (2) andesitic rock with a dark matrix with feldspar blasts (arrow 2) and (3) medium grained granodiorite-porphyry with enclaves of phases 1 and 2 (arrow 3); chilled margin between the andesite and granodiorite-porphyry and the magmatic enclaves (MME) are typical for mingling phenomena (arrow 4). The Sr-Nd isotopic ratios of the Buchim area are plotted (Fig. 7A) together with similar rock types from Serbia and Bulgaria. The depleted mantle (DM) and continental crust fields (DePaolo and Wasserburg, 1979; McCulloch et al., 1983) and very young magmatic rocks from F.Y.R.O.M. are added to the diagram for comparison (Fig. 7B). All available isotope data of Oligocene igneous rocks (Cvetković et al., 2004; Graf, 2001; Kounov et al., 2013; Marchev et al., 2004; Prelević et al., 2005) and the new obtained analyses from the Buchim area fit very well on an evolution trend between a depleted mantle composition and the Variscan basement field (Peytcheva et al., 2009; von Quadt et al., 2005). It seems that the geochemical-isotopic evolution of the Buchim area can be explained by a mixing curve between two end members (Fig. 7A).

Geochronological data of the Serbo-Macedonian Massif reveals the existence of a Cadomian arc magmatism between 540 and $577 \mathrm{Ma}$ (Graf, 2001; Kounov et al., 2012) and the Variscan basement between 330 and $305 \mathrm{Ma}$ (von Quadt et al., 2005) with isotope-geochemical fingerprints of $\varepsilon$-Nd values between -8 and -4.5 (calculated for $24 \mathrm{Ma}$ ). Fig. 7B uses the ${ }^{143} \mathrm{Nd} /{ }^{144} \mathrm{Nd}$ ratio versus time (in Ma) relationship to show individual characteristics of time-dependent magmatism. The Sr-Nd values for the Cadomian and Variscan basement (Fig. 7A; Kounov et al., 2012; von Quadt et al., 2005) probably represent one part of the continental crust (EM II).

In order to understand the magmatic evolution of the area we plotted the Nd isotope signatures for several periods (Fig. 7B), 29$35 \mathrm{Ma}, 18-26 \mathrm{Ma}$ and 1-4 Ma. The magmatic period during Oligocene time (29-35 Ma, Fig. 7B) is dominated by crustal melting, whereas the magmatism in Late Oligocene/Early Miocene (20-27 Ma) displays a higher portion of a mantle component (Fig. 7B). The Pliocene magmatic event shows similarities in $\mathrm{Nd}-\mathrm{Sr}$ characteristics to the Oligocene magmatism (Fig. 7B).

\subsection{Age of the intrusions}

All intrusions in the Buchim-Damjan-Borov Dol area occurred in a narrow time span between $24.19 \pm 0.62 \mathrm{Ma}$ and $24.51 \pm 0.89 \mathrm{Ma}$, i.e., during the latest Oligocene. This means that the magmatic activity has a life span of 320,000 years. Since the zircon ages are very close together, it is not possible to determine a time sequence of the intrusions. The chemical annealing method has removed all damaged domains that had lost $\mathrm{Pb}$, and the individual analysis of the residual zircons gave mostly good concordant ages and less scattered ${ }^{206} \mathrm{~Pb} /{ }^{238} \mathrm{U}$ ages. No old cores are visible on CL images and no inherited old $\mathrm{U} / \mathrm{Pb}$ ages were measured; therefore, we can rule out the possibility that an assimilation process was involved within the magma chamber. As mentioned earlier, the Buchim-Damjan-Borov Dol ore district is part of the Late Eocene-Oligocene magmatic belt (Schefer et al., 2011; 
Serafimovski et al., 2010). The intrusions of the district fit very well in the NE to SW younging direction of the magmatism (Heinrich and Neubauer, 2002; Schefer et al., 2011). Furthermore the Late Eocene-Oligocene magmatic belt crosscuts older tectonic structures (Schmid et al., 2008), which shows that there is a new subduction zone (Fig. 1).

\subsection{Tectonic setting}

Here we consider the relationship between melt geochemical variation, emplacement age, and sample location as a basis for interpreting the spatio-temporal evolution of the Oligocene magmatic systems.

From this we derive a lithosphere-scale tectonic model for the interaction between the African-Adriatic lithospheric slab in SE Balkan during Eocene-Oligocene times. Calc-alkaline, high-K and shoshonitic geochemical characteristics, including enrichment in LILE and depletion in HFSE, point to a subduction-related or extension-related origin for the Oligocene magmatic system. This Eocene-Oligocene magmatism was more linearly oriented (NW-SE) cross-cutting the pre-EoceneOligocene deformation, e.g. all major tectonic boundaries of the Balkan Peninsula (Fuegenschuh and Schmid, 2005; Ustaszewski et al., 2008; Fig. 1). Several broadly subduction-related tectonic models have been proposed to explain the evolution of the Cretaceous and EoceneOligocene magmatic arcs, including extensional rifting associated with orogenic collapse (Berza et al., 1998; Bojar et al., 1998; Iancu et al., 2005; Willingshofer et al., 2001), or rollback of a subducting oceanic slab (Burg, 2012; Lips et al., 2002; von Quadt et al., 2005; Zimmerman et al., 2008). The slab rollback model implies a gradual steepening of a northward subducting lithosphere slab, derived from the Jurassic to Cretaceous Vardar ocean (van Hinsbergen et al., 2005). New geochronological data support the idea that the slab is continuously moving to the south or southwest (Kirchenbaur et al., 2012; Peytcheva et al., 2012; van Hinsbergen et al., 2005; van Hinsbergen and Schmid, 2012; von Quadt et al., 2005). The rollback process leads to an upper plate extension, corner flow within the asthenosphere, and partial melting of the mantle wedge. Upper-crustal extension allows mantle-derived melts to access higher crustal levels. High magmatic volatile contents and extensive magmatic differentiation processes are one key to the formation of metalliferous hydrothermal magmatic fluids. These fluids, forming the ore deposits, are exsolved during the late stages of magmatic evolution after the emplacement of the magmas in the upper crust (e.g. Hedenquist and Lowenstern, 1994). The extension process in the Eocene-Oligocene (Burchfiel et al., 2008) leads to the building of new sedimentary basins. Prelević et al. (2008) preferred an orogenic collapse model as part of the postcollisional volcanism for the origin of the Serbian lamproites (Tertiary in age). A recent paper by van Hinsbergen and Schmid (2012) investigated the extension of the Aegean region (Greece) since the Eocene and they proposed a $400 \mathrm{~km}$ extension from NE to SW. The authors suggest that there is a decoupling between upper crustal slices and the African-Adriatic lithospheric slab and the distance between the trace of subduction and the occurrences at the Buchim area includes a distance of $200 \mathrm{~km}$ during Oligocene time; the distance of $200 \mathrm{~km}$ allows an interpretation of subductionrelated as well as extensional-related magmatism. The strong link between $\mathrm{Cu}-\mathrm{Au}$ porphyry deposits, and subduction-related and extensional-related magmatism has been demonstrated several times (Chiaradia et al., 2011; Heinrich and Neubauer, 2002; Richards, 2003; von Quadt et al., 2005). Here we provide evidence for the late Oligocene age and typical isotopic-geochemical affinities of these rocks. As demonstrated above, the rocks of the Buchim-DamjanBorov Dol region, together with other Oligocene rocks, e.g. the Osogovo granite (31 Ma, Kounov et al., 2013) close to the Buchim region (30 km to the north), show typical fingerprints of recycled Variscan/Cadomian crust material and newly formed mantle-like material in stages with different proportions of mixing material (Schefer et al., 2011; Schmid et al., 2008). A later tectonic process in the region around Buchim-
Damjan-Borov Dol leads to thrust faulting after the emplacement of several magmatic dykes. This thrusting led to relative uplift of the Buchim-Damjan-Borov Dol ore district and also to a higher erosion rate in this part (Burchfiel et al., 2008). Field observations suggest an $800-1000$ m vertical uplift of the Borov Dol segment in respect to the western part and, for the Buchim segment, again $1000 \mathrm{~m}$ against the Borov Dol segment (Fig. 2B). This provides the present-day view into a shallow magma chamber of the Borov Dol intrusion and leads to the conclusion that the magma intruded into the tuff layers which have their origin in a different and older eruption.

\section{Conclusion}

The $\mathrm{Cu}-\mathrm{Au}$ bearing porphyritic intrusions of the Buchim-DamjanBorov Dol ore district belong to the Late Eocene-Oligocene magmatism which occur in Bulgaria, Serbia, Kosovo and F.Y.R.O.M. The trace of this magmatism and their subducted slab does not follow any main and known tectonic alignments. The presented geochemical data indicate that the Buchim-Damjan-Borov Dol region formed by crystallization of Variscan/Cadomian crustal material and newly formed crust components with mantle-like affinities in variable proportions. Sr-Nd whole rock data and $\varepsilon$-Hf zircon analyses demonstrate a simple twocomponent mixing process. The addition of volatiles associated with these magma mixing processes was responsible for magmatichydrothermal $\mathrm{Cu}-\mathrm{Au}$ mineralization in the porphyry intrusion or in the surrounding the host rocks (gneiss).

The REE distribution pattern of the whole rock data and the zircons indicate with a weak negative Eu anomaly that the plagioclase crystallized in an early phase of the magma generation. $\mathrm{Sr} / \mathrm{Y}$ and $\mathrm{La} / \mathrm{Yb}$ ratios show that a minor part of the rocks have adakite-like signatures, most of them are linked to typical geochemical features of an island arc/calc-alkaline character. Microprobe analyses on amphiboles lead to three stages of the magma evolution, e.g. at $20 \mathrm{~km}, 12 \mathrm{~km}$ and $5.8 \mathrm{~km}$ depth.

It is not possible to present a time sequence of the individual intrusions according to the $\mathrm{U}-\mathrm{Pb}$ zircon dating. All intrusion ages of the Buchim-Damjan-Borov Dol region are overlapping within their analytical errors between $24.19 \pm 0.62 \mathrm{Ma}$ and $24.51 \pm 0.89 \mathrm{Ma}$. The Buchim-Damjan-Borov Dol ore District was active during the late Oligocene/early Miocene period (Aquitanian). Field data show a clear relationship that the Vrsnik intrusion is younger than the Central intrusion. Due to the Miocene tectonic scenario, e.g., extension with the building of basins, and crustal shortening together with the associated thrust faults, several parts of the ore deposits were probably eroded. The Borov Dol intrusion region allows a view into a shallow magma because extrusive rocks (tuffs) occur around Borov Dol, probably derived from an earlier magmatic phase with clearly different geochemical characteristics.

Supplementary data to this article can be found online at http://dx. doi.org/10.1016/j.lithos.2013.09.002.

\section{Acknowledgments}

The authors thank: Mite Mitev, Kircho Filev, Goran Tasev and Violeta Stefanova for support in the field. Additionally we thank the SCOPES project (Project-No. IZ73Z0-128089) for financial support. We thank two reviewers, Svetoslav Georgiev and Istvan Marton, for their critical view, suggestions and help to publish the paper.

\section{Appendix 1. Analytical methods}

\subsection{Major and trace elements in rocks}

Whole rock analyses for major elements were carried out on Li-tetraborate pellets (lithium-tetraborate with a 1:5 mixture of Claisse M4® fluxer) using the X-ray fluorescence method (XRF; ETH Zürich). Trace element and REE determinations were conducted with laser 
ablation-inductively coupled plasma-mass spectrometry (LA-ICP-MS) on the same Li-tetraborate pellets and on the zircon grains. The machine is equipped with an Excimer laser (ArF $193 \mathrm{~nm}$ ) and a PE SCIEX Elan 6100 DRC ICPMS. The spot size of the laser was $40 \mu \mathrm{m}$, and for calibration the NIST 610 standard was used (Günther et al., 2001; Halter et al., 2004).

\subsection{Sr-Nd-analysis}

An isotope analysis set for $\mathrm{Sr}$ and Nd was performed on whole-rock powder (50-100 mg). The isotopic composition of $\mathrm{Sr}$ and $\mathrm{Nd}$ and the $\mathrm{Rb}, \mathrm{Sr}, \mathrm{Sm}$ and Nd concentrations were measured at ETH Zürich using a TritonPlus Mass spectrometer (TIMS). Values for ${ }^{87} \mathrm{Sr} /{ }^{86} \mathrm{Sr}$ were internally corrected for fractionation using a ${ }^{88} \mathrm{Sr} /{ }^{86} \mathrm{Sr}$ value of 8.37521. Repeated measurements of the NBS 987 standard gave a mean value of $0.710252 \pm 0.000002(2 \sigma) .{ }^{143} \mathrm{Nd} /{ }^{144} \mathrm{Nd}$ values were internally corrected for mass fractionation using a ${ }^{146} \mathrm{Nd} /{ }^{144} \mathrm{Nd}$ value of 0.7219 . No correction on Nd was performed due to good segregation of Nd and Sm during column chemistry. Repeated measurements on the Nd Merck standard gave a mean value of $0.511730 \pm 0.000001(2 \sigma)$. Age-corrected ( $\mathrm{t}=24 \mathrm{Ma}$; measured $\mathrm{U}-\mathrm{Pb}$ zircon age $){ }^{87} \mathrm{Sr} /{ }^{86} \mathrm{Sr}$ and ${ }^{143} \mathrm{Nd} /{ }^{144} \mathrm{Nd}$ values were calculated using $\mathrm{Rb}, \mathrm{Sr}, \mathrm{Sm}$ and Nd concentrations determined by LA-ICP-MS.

\subsection{Analytical method of zircon analysis}

The zircons were separated from the host rock by SelFrag High Voltage Pulse Power Fragmentation and density separation with methylene iodide. The crystals were chemically abraded, to remove the disturbed domains, by using thermal annealing and selective leaching (Mattinson, 2005).

Afterwards they were embedded in epoxy resin. With the CamScan scanning electron microscope (SEM) cathodoluminisence $(\mathrm{CL})$ and back-scattered (BSE) images were taken at the Electron Microscopy group ETH Zürich (EMEZ) to select the zones for the analyses.

The LA-ICP-MS analyses were carried out in blocks of 26 measurements including sample and standards. The machine is equipped with an Excimer $193 \mathrm{~nm}$ laser and an Elan 6100 DRC ICP-MS. The ablation size was $40 \mu \mathrm{m}$ and had a frequency of $10 \mathrm{~Hz}$. For the calibration two zircon standards were used GJ-1 (Jackson et al., 2004) and Plešovice (Slama et al., 2008). The standards were measured at the beginning, middle and end of a block. The age calculation was done with GLITTER (van Achterbergh et al., 2001). The dates were plotted with ISOPLOT (Ludwig, 2003). ${ }^{206} \mathrm{~Pb} /{ }^{238} \mathrm{U}$ and ${ }^{207} \mathrm{~Pb} /{ }^{206} \mathrm{~Pb}$ ages were corrected for initial disequilibrium in ${ }^{230} \mathrm{Th} /{ }^{238} \mathrm{U}$ using $\mathrm{Th} / \mathrm{U}$ [magma] = 3.17 [059-1], 3.70 [029-5], 4.84 [029-1], 3.23 [268-1A], 3.03 [238-3], 3.21 [278D-1], 2.52 [248-2], and 5.09 [Black Hill]. The calculated age only considers concordant zircon-ages and is the mean of the ${ }^{206} \mathrm{~Pb} /{ }^{238} \mathrm{U}$ age. The error is a 1-sigma uncertainty.

\section{References}

Belousova, E.A., Griffin, W.L., O'Reilly, S.Y., Fisher, N.I., 2002. Igneous zircon: trace element composition as an indicator of source rock type. Contributions to Mineralogy and Petrology 143, 602-622.

Berza, T., Constantinescu, E., Vlad, S.N., 1998. Upper Cretaceous magmatic series and associated mineralisation in the Carpathian-Balkan orogen. Resource Geology 48 (4), 291-306.

Blundy, J.D., Holland, T.J.B., 1990. Calcic amphibole equilibria and a new amphiboleplagioclase geothermometer. Contributions to Mineralogy and Petrology 104 (2), 208-224.

Bojar, A.V., Neubauer, F., Fritz, H., 1998. Cretaceous to Cenozoic thermal evolution of the southwestern South Carpathians: evidence from fission-track thermochronology. Tectonophysics 297, 229-249.

Bortolotti, V., Marroni, M., Pandolfi, L., Principi, G., 2005. Mesozoic to Tertiary tectonic history of the Mirdita ophiolites, northern Albania. Island Arc 14, 471-493.

Browne, B.L., Eichelberger, J.C., Patino, L.C., Vogel, T.A., Uto, K., Hoshizumi, H., 2006. Magma mingling as indicated by texture and $\mathrm{Sr} / \mathrm{Ba}$ ratios of plagioclase phenocrysts from Unzen volcano, SW Japan. Journal of Volcanology and Geothermal Research $154,103-116$.
Burchfiel, B.C., Nakov, R., Dumurdzanov, N., Papanikolaou, D., Tzankov, T., Serafi movski, T., King, R.W., Kotzev, V., Todosov, A., Nurce, B., 2008. Evolution and dynamics of the Cenozoic tectonics of the South Balkan extensional system. Geosphere 4, 919-938.

Burg, J.P., 2012. From Mesozoic convergence to Cenozoic extension. Review of petrostructural data in the geochronological frame. Journal of the Virtual Explorer. In: Skourtsos, E., Lister, G.S. (Eds.), The Geology of Greece 39, 1-44.

Castillo, P.R., Janney, P.E., Solidum, R.U., 1999. Petrology and geochemistry of Camiguin Island, southern Philippines: insights to the source of adakites and other lavas in a complex arc setting. Contributions to Mineralogy and Petrology 134, 33-51.

Chiaradia, M., Müntener, O., Beate, B., 2011. Enriched basaltic andesites from mid-crustal fractional crystallization, recharge, and assimilation (PilavoVolcano, Western Cordillera of Ecuador). Journal of Petrology 52 (6), 1107-1141.

Cifliganec, V., 1993. Copper Mineralization in the Republic of Macedonia: Types and Distribution Patterns. University Skopje Faculty of Mining and Geology-Stip (Special Issue No1).

Cvetković, V., Prelević, D., Pecskay, Z., 2000. Lamprophyric rocks of the Miocene Borač Eruptive Complex (Central Serbia, Yugoslavia). Acta Geologica Hungarica 43 (1), 25-41.

Cvetković, V., Prelević, D., Downes, H., Jovanović, M., Vaselli, O., Pécskay, Z., 2004. Origin and geodynamic significance of Tertiary postcollisional basaltic magmatism in Serbia (central Balkan Peninsula). Lithos 73, 161-186.

Davidson, J.P., Morgan, D.J., Charlier, B.L.A., Harlou, R., Hora, J.M., 2007. Microsampling and isotopic analysis of igneous rocks: implications for the study of magmatic systems. Annual Review of Earth and Planetary Sciences 273-311.

Defant, M.J., Drummond, M.S., 1990. Derivation of some modern arc magmas by melting of young subducted lithosphere. Nature 347, 662-665.

Del Moro, A., Innocenti, F., Kyriakopoulos, C., Manetti, P., Papadopoulos, P., 1988. Tertiary granitoids from Thrace (Northern Greece): Sr isotopic and petrochemical data. Neues Jahrbuch Mineralogische Abhandlungen 159 (2), 113-135.

Depaolo, D.J., Wasserburg, G.J., 1979. Petrogenetic mixing models and $\mathrm{Nd}-\mathrm{Sr}$ isotopic patterns. Geochimica et Cosmochimica Acta 43, 615-627.

Dumurdzanov, N., Serafimovski, T., Burchfiel, B.C., 2005. Cenozoic tectonics of Macedonia and its relation to the South Balkan extensional regime. Geosphere 1,1-22.

Frei, R., 1992. Isotope (Pb, Rb-Sr, S, O, C, U-Pb) Geochemical Investigations on Tertiary Intrusives and Related Mineralizations in the Serbomacedonian $\mathrm{Pb}-\mathrm{Zn}, \mathrm{Sb}+\mathrm{Cu}-$ Mo Metallogenetic Province in Northern Greece. (Ph.D. dissertation) ETH, Zürich.

Fuegenschuh, B., Schmid, St, 2005. Age and significance of core complex formation in a very curved orogen: evidence from fission track studies in the South Carpathians (Romania). Tectonophysics 404, 33-53.

Georgiev, S., Marchev, P., Heinrich, C.A., von Quadt, A., Peytcheva, I., 2009. Origin of nepheline-normative high-K ankaramites and the evolution of eastern Srednogorie arc in southeastern Europe. Journal of Petrology 50, 1899-1933.

Georgiev, S., von Quadt, A., Heinrich, C.A., Peytcheva, I., Marchev, P., 2012a. Time evolution of a rifted continental arc: integrated ID-TIMS and U-Pb LA-ICPMS study of magmatic zircons from the Eastern Srednogorie, Bulgaria. Lithos. http://dx.doi.org/10.1016/ j.lithos.2012.06.020.

Georgiev, St, Peytcheva, I., Stefanova, E., von Quadt, A., Marchev, P., Grozdev, V., Serafimowski, T., 2012b. Geochemistry and geochronology of Ilovitsa magmatic rocks, SE FYR Macedonia. International Earth Science Colloq Aegean Region, IESCA2012, 1.-5.October 2012. Izmir, Turkey, p. 94.

Gilg, H.A., Frei, R., Kalogeropoulos, S.I., Nicolaou, M., 1992. Metamorphism and polygenesis of the Madem Lakkos polymetallic sulfide deposit, Chalkidiki, Greece-a discussion. Economic Geology and the Bulletin of the Society of Economic Geologists 87, 1184-1193.

Graf, J., 2001. Alpine tectonics in Western Bulgaria: Cretaceous compression of the Kraishte region and Cenozoic exhumation of the crystalline Osogovo-Lisets Complex, Unpubl. doctoral dissertation, ETH, Zurich.

Günther, D., von Quadt, A., Wirz, R., Cousin, H., Dietrich, V.J., 2001. Elemental analyses using laser ablation-inductively coupled plasma-mass spectrometry (LA-ICP-MS) of geological samples fused with $\mathrm{Li}_{2} \mathrm{~B}_{4} \mathrm{O}_{7}$ and calibrated without matrix-matched standards. Mikrochimica Acta 136, 101-107.

Halter, W.E., Bain, N., Becker, K., Heinrich, C.A., Landtwing, M., von Quadt, A., Clark, A.H., Sasso, A.M., Bissig. T., Tosdal, R.M., 2004. From andesitic volcanism to the formation of a porphyry Cu-Au mineralizing magma chamber: the Farallon Negro Volcanic Complex, northwestern Argentina. Journal of Volcanology and Geothermal Research 136, 1-30.

Harkovska, A., Yanev, Y., Marchev, P., 1989. General features of the Paleogene orogenic magmatism in Bulgaria. Geologica Balcanica 19, 37-72.

Hastie, A.R., Kerr, A.C., Pearce, J.A., Mitchell, S.F., 2007. Classification of altered volcanic island arc rocks using immobile trace elements: development of the Th-Co discrimination diagram. Journal of Petrology 48, 2341-2357.

Hedenquist, J.W., Lowenstern, J.B., 1994. The role of magmas in the formation of hydrothermal ore deposits. Nature 370, 519-527.

Heinrich, C.A., Neubauer, F., 2002. Cu-Au-Pb-Zn-Ag metallogeny of the Alpine-BalkanCarpathian-Dinaride geodynamic province. Mineralium Deposita 37, 533-540.

Hoskin, P.W.O., Ireland, T.R., 2000. Rare earth element chemistry of zircon and its use as a provenance indicator. Geology 28, 627-630.

Hoskin, P.W.O., Schaltegger, U., 2003. The composition of zircon and igneous and metamorphic petrogenesis. In: Hanchar, J.M., Hoskin, P.W.O. (Eds.), Zircon. Reviews in Mineralogy \& Geochemistry, 53, pp. 27-62.

Hristov, S., Karajovanovik, M., Stračkov, M.,1973. Kavadarci, Basic Geological Map 1:100000. Federal Geological Survey, Belgrade.

Iancu, V., Berza, T., Seghedi, A., Gheuca, I., Hann, H.P., 2005. Alpine polyphase tectonometamorphic evolution of the South Carpathians: a new overview. Tectonophysics 410 (1-4), 337-365.

Jackson, S.E., Pearson, N.J., Griffin, W.L., Belousova, E.A., 2004. The application of laser ablation-inductively coupled plasma-mass spectrometry to in situ U-Pb zircon geochronology. Chemical Geology 211, 47-69. 
Jahn, B.M., Glikson, A.Y., Peucat, J.J., Hickman, A.H., 1981. REE Geochemistry and isotopic data of Archean silicic volcanics and granitoids from the Pilbara block, Western-Australia implications for the early crustal evolution. Geochimica Et Cosmochimica Acta 45 (9), $1633-1652$.

Jahn-Awe, S., Froitzheim, N., Nagel, T.J., Frei, D., Georgiev, N., Pleuger, J., 2010. Structural and geochronological evidence for Paleogene thrusting in the western Rhodopes, SW Bulgaria: elements for a new tectonic model of the Rhodope Metamorphic Province. Tectonics 29. http://dx.doi.org/10.1029/2009TC002558.

Jahn-Awe, S., Pleuger, J., Frei, D., Georgiev, N., Froitzheim, N., Nagel, T.J., 2012. Time constraints for low-angle shear zones in the Central Rhodopes (Bulgaria) and their significance for the exhumation of high-pressure rocks. International Journal of Earth Sciences 101, 1971-2004. http://dx.doi.org/10.1007/s00531-012-0764-5.

Kirchenbaur, M., Pleuger, J., Jahn-Awe, S., Nagel, T.J., Froitzheim, N., Fonseca, R.O.C., Münker, C., 2012. Timing of high-pressure metamorphic events in the Bulgarian Rhodopes from Lu-Hf garnet geochronology. Contributions to Mineralogy and Petrology 163, 897-921.

Kolb, M., von Quadt, A., Peytcheva, I., Heinrich, C.A., Fowler, S.J., Cvetkovic, V., 2012 Adakite-like and normal arc magmas: distinct fractionation paths in the East Serbian segment of the Balkan-Carpathian Arc. Journal of Petrology 1-31. http:// dx.doi.org/10.1093/petrology/egs072.

Koroneos, A., Poli, G., Cvetković, V., Christofides, G., Krstić, D., Pecskay, Z., 2011. Petrogenesis and tectonic inferences from the study of the Mt. Cer pluton (West Serbia). Geological magazine 148 (1), 89-111.

Kounov, A., Graf, J., von Quadt, A., Bernoulli, D., Burg, J.P., Seward, D., Ivanov, Zh., Fanning, M., 2012. Evidence for a "Cadomian" ophiolite and magmatic-arc complex in SW Bulgaria. Precambrian Research 212-213, 275-295.

Kounov, A., Graf, J., von Quadt, A., Bernoulli, D., Burg, J.P., Seward, D., Ivanov, Zh., Fanning, M., 2013. Oligocene magmatism in the Kraishte zone, SW Bulgaria. Terra Nova (Submitted for publication).

Kyriakopoulus, G.K., 1987. Geochronological, geochemical, mineralogical study of tertiary plutonic rocks of Rhodope massif and their ( $\mathrm{Rb}-\mathrm{Sr}$ and $\mathrm{K}-\mathrm{Ar}$ ) isotopic characteristics. PhD Thesis Department of geology Athens University, p. 343.

Le Maitre, R.W.B.P., Dudek, A., Keller, J., Lameyer Le Bas, M.J., Sabine, P.A., Schmid, R. Sorensen, H., Streckeisen, A., Woolley, A.R., Zanettin, B., 1989. A Classification of Igneous Rocks and Glossary of Terms. Oxford.

Leake, B.E., Woolley, A.R., Arps, C.E.S., Birch, W.D., Gilbert, M.C., Grice, J.D., Hawthorne, F.C. Kato, A., Kisch, H.J., Krivovichev, V.G., Linthout, K., Laird, J., Mandarino, J., Maresch, E.H., Nickel*, N.M.S., Rock, J.C., Schumacher, D.C., Smith, N.C.N., Stephenson, L., Ungaretti, W.V., Whittaker, E.J.W., Youzhi, G., 1997. Nomenclature of amphiboles: report of the subcommittee on amphiboles of the International Mineralogical Association, Commission on New Minerals and Mineral Names. American Mineralogist 82, 1019-1037.

Lehmann, S., Barcikowski, J., von Quadt, A., Heinrich, C.A., Schmid, S., Serafimowski, T. 2012. Magmatic evolution of the Buchim-Damjan-Borov Dol ore district, Macedonia Unpubl. MSc Thesis, ETH, Zürich.

Lilov, P., Yanev, Y., Marchev, P., 1987. K / Ar dating of the Eastern Rhodopes Paleogene magmatism. Geologica Balcanica 17, 49-58.

Lips, A.L.W., White, St, Wijbrans, J.R., 2002. Middle-Late Alpine thermotectonic evolution of the southern Rhodope Massif, Greece. Geodinamica Acta 13, 281-292.

Ludwig, K.R., 2003. Mathematical-statistical treatment of data and errors for Th-230/U geochronology. Uranium-Series Geochemistry 52, 631-656.

Marchev, P., Singer, B., 2002. ${ }^{40} \mathrm{Ar} /{ }^{39} \mathrm{Ar}$ geochronology of magmatism and hydrothermal activity of the Madjarovo base-precious metal ore district, eastern Rhodopes, Bulgaria. Geological Society Special Publication 204, 137-150.

Marchev, P., Raicheva, R., Downes, H., Vaselli, O., Chiaradia, M., Moritz, R., 2004. Compositional diversity of Eocene-Oligocene basaltic magmatism in the Eastern Rhodopes, SE Bulgaria: implications for genesis and tectonic setting. Tectonophysics 393, 301-328.

Marchev, P., Kaiser-Rohrmeier, M., Heinrich, C.A., Ovtcharova, M., von Quadt, A., Raicheva R., 2005. Hydrothermal ore deposits related to post-orogenic extensional magmatisn and core complex formation: the Rhodope Massif of Bulgaria and Greece. Ore Geology Reviews 27, 53-89.

Marchev, P., Kibarov, P., Spikings, R., Ovtcharova, M., Márton, I., Moritz, R., $2010 .{ }^{40} \mathrm{Ar} /{ }^{39} \mathrm{Ar}$ and $\mathrm{U}-\mathrm{Pb}$ geochronology of the Iran Tepe volcanic complex, Eastern Rhodopes. Geologica Balcania 39, 3-12.

Martin, H., Smithies, R.H., Rapp, R., Moyen, J.-F., Champion, D., 2005. An overview of adakite, tonalite-trondhjemite-granodiorite (TTG), and sanukitoid: relationships and some implications for crustal evolution. Lithos 79, 1-24

Mattinson, J.M., 2005. Zircon U-Pb chemical abrasion ("CA-TIMS") method: combined annealing and multi-step partial dissolution analysis for improved precision and accuracy of zircon ages. Chemical Geology 220, 47-66.

McCulloch, M.T., Jaques, A.L., Nelson, D.R., Lewis, J.D., 1983. Nd and Sr isotopes in kimberlites and Lamproites from Western-Australia-an enriched mantle origin. Nature 302 400-403.

Melfos, V., Vavelidis, M., Christofides, G., Seidel, E., 2002. Origin and evolution of the Tertiary Maronia porphyry copper-molybdenum deposit, Thrace, Greece. Mineralium Deposita 37, 648-668.

Müller, D., Rock, N.M.S., Groves, D.I., 1992. Geochemical discrimination between shoshonitic and potassic volcanic-rocks in different tectonic settings-a pilot-study. Mineralogy and Petrology 46, 259-289.

Ovtcharova, M., von Quadt, A., Cherneva, Z., Sarov, S., Heinrich, C., Peytcheva, I., 2004 $\mathrm{U}-\mathrm{Pb}$ dating of zircon and monazite from granitoids and migmatites in the core and eastern periphery of the Central Rhodopean Dome, Bulgaria. Geochimica et Cosmochimica Acta 68, A664.

Pearce, J.A., 1982. Trace element characteristics of lavas from destructive plate boundaries. In: Thorpe, R.S. (Ed.), Andesites. Wiley, Chichester, pp. 525-548.

Pearce, J.A., 1983. Role of the sub-continental lithosphere in magma genesis at active continental margins. In: Hawkeswoth, C.J., Norry, M.J. (Eds.), Continetal Basalts and Mantle Xenoliths. Shiva, Nantwich, pp. 230-249.
Pecskay, Z., Eleftheriadis, G., Koroneos, A., Soldatos, T., Christofides, G., 2003. K/Ar dating, geochemistry and evolution of the Tertiary volcanic rocks (Thrace, northeastern Greece). Mineral exploration and sustainable development 1-2, 1229-1232.

Pe-Piper, G., 1998. The nature of Triassic extension-related magmatism in Greece: evidence from $\mathrm{Nd}$ and $\mathrm{Pb}$ isotope geochemistry. Geological Magazine 135, 331-348.

Pe-Piper, G., Piper, D.J.W., 2001. Late Cenozoic, post collisional Aegean igneous rocks: Nd, $\mathrm{Pb}$ and $\mathrm{Sr}$ isotopic constraints on petrogenetic and tectonic models. Geological Magazine 138, 653-668.

Pe-Piper, G., Piper, D.J.W., 2002. The igneous rocks of Greece. The Anatomy of an Orogeny, 573

Peytcheva, I., et al., 2009. U-Pb dating, Hf-isotope characteristics and trace-REE-patterns of zircons from Medet porphyry copper deposit, Bulgaria: implications for timing, duration and sources of ore-bearing magmatism. Mineralogy and Petrology 96 , $19-41$.

Peytcheva, I., von Quadt, A., Marchev, P., Harkovska, A., Grozdev, V., Georgiev, S., 2012 Age and isotope-geochemical characteristics of the Tertiary magmatism in Kraishte region, W Bulgaria. International Earth Science Colloquium on the Aegean Region, 1-5 Oct. 2012, 73. Izmir, Turkey.

Popov, P., 1981. Magmotectonic features of the Banat-Srednogorie belt. Geologica Balcanica $11,43-72$

Popov, P., 1987. Tectonics of the Banat Srednogorie rift. Tectonophysics 143, 209-216.

Popov, P., Berza, T., Grubic, A., Ioane, D., 2002. Late Cretaceous Apuseni-Banat-TimokSrednogorie(ABTS) magmatic and metallogenic belt in the Carpathian-Balkan orogen. Geologica Balcanica 32, 145-162.

Prelević, D., Foley, S.F., Romer, R.L., Cvetković, V., Downes, H., 2005. Tertiary ultrapotassic volcanism in Serbia: constraints on petrogenesis and mantle source characteristics. Journal of Petrology 46, 1443-1487.

Prelević, D., Foley, S.F., Romer, R., Conticelli, S., 2008. Mediterranean Tertiary lamproites derived from multiple source components in postcollisional geodynamics. Geochemica et Cosmochimica Acta 72, 2125-2156.

Putirka, K.D.T., Fran III, J., 2008. Minerals, inclusions and volcanic processes. Reviews in Mineralogy and Geochemistry 69, 674.

Richards, J.P., 2003. Tectono-magmatic precursors for porphyry $\mathrm{Cu}-(\mathrm{Mo}-\mathrm{Au})$ deposits formation. Economic Geology 98, 1515-1533.

Rickwood, P.C., 1989. Boundary lines within petrologic diagrams which use oxides of major and minor elements. Lithos 22, 247-263.

Rohrlach, B.D., Loucks, R.R., 2005. Multi-million-year cyclic ramp-up of volatiles in a lower crustal magma reservoir trapped below the Tampakan copper-gold deposit by Mio-Pliocene crustal compression in the southern Philippines. In: Porter, T.M. (Ed.), Super Porphyry Copper \& Gold Deposits. PGC Publishing, Australia, pp. 369-407.

Rollinson, H., 1993. Using geochemical data: evaluation, presentation, interpretation. Geochemistry Series, 1, 352. Longman Scientific \& Technical, Singapore.

Ruprecht, P., Woerner, G., 2007. Variable regimes in magma systems documented in plagioclase zoning patterns: El Misti stratovolcano and Andahua monogenetic cones. Journal of Volcanology and Geothermal Research 165, 142-162.

Saccani, E., Photiades, A., Santato, A., Zeda, O., 2008. New evidence for supra-subduction zone ophiolites in the Vardar Zone of northern Greece: implications for the tectono-magmatic evolution of the Vardar oceanic basin. Ofioliti 33, 65-85.

Schefer, S., Cvetkovic, Fügenschuh, B., Kounov, A., Ovtcharova, M., Schaltegger, U., Schmid, S.M., 2011. Cenozoic granitoids in the Dinarides of southern Serbia: age of intrusion, isotope geochemistry, exhumation history and significance for the geodynamic evolution of the Balkan Peninsula. International Journal of Earth Sciences 100, 1181-1206.

Schmid, S.M., Bernoulli, D., Fügenschuh, B., Matenco, L., Schefer, S., Schuster, R., Tischler, M. Ustaszewski, K., 2008. The Alpine-Carpathian-Diednaridic orogenic system: correlation and evolution of tectonic units. Swiss Journal of Geosciences 101, 139-183.

Schmid, S.M., Bernoulli, D., Fügenschuh, B., Kounov, A., Oberhänsli, R., Schefer, S., van Hinsbergen, D., Ustaszewski, K., 2011. Similarities and differences between Alps Carpathians. Dinarides-Hellenides and Anatolides-Taurides, AGU Fall Meeting.

Schmidt, M.W., 1992. Amphibole composition in tonalite as a function of pressure-an experimental calibration of the Al-in-hornblende barometer. Contributions to Mineralogy and Petrology 110 (2-3), 304-310.

Serafimovski, T., Boev, B., 1996. Metallogeny of the Kratovo-Zletovo volcano-intrusive complex. Terranes of Serbia 356, 347-352.

Serafimovski, T., Cifliganec, V., Jankovic, S., Boev, B., 1996. Genetic model of the Buchim porphyry copper deposit, Republic of Macedonia. In: Popov, P.D.S.P. (Ed.), Plate Tectonic Aspects of the Alpine Metallogeny in the Carpatho-Balkan Region. The University of Mining and Geology "St. Ivan Rilski”, Sofia, pp. 63-74.

Serafimovski, T., Jankovic, S., Cjfliganec, V., 1997. Principal metallogenic features of the Lece-Cahlkidiki zone. Romanian Journal of Mineral Deposits 78, 93-105.

Serafimovski, T., Stefanova, V., Volkov, A.V., 2010. Dwarf copper-gold porphyry deposits of the Buchim-Damjan-Borov Dol ore district, Republic of Macedonia (FYROM). Geology of Ore Deposits 52, 179-195.

Singer, B., Marchev, P., 2000. Temporale evolution of arc magmatism and hydrothermal activity, including epithermal gold veins, Borovitsa caldera, Southern Bulgaria. Economic Geology 95, 1155-1164.

Slama, J., Košler, J., Condon, D.J., Crowley, J.L., Gerdes, A., Hanchar, J.M., Horstwood, M.S.A. Morris, G.A., Nasdala, L., Norberg, N., Schaltegger, U., Schoene, B., Tubrett, M.N., Whitehouse, M.J., 2008. Plesovice zircon-a new natural reference material for $\mathrm{U}-\mathrm{Pb}$ and Hf isotopic microanalysis. Chemical Geology 249, 1-35.

Smith, V.C., Blundy, J.D., Arce, J.L., 2009. A temporal record of magma accumulation and evolution beneath Nevado de Toluca, Mexico, preserved in plagioclase phenocrysts. Journal of Petrology 50, 405-426.

Snyder, G.A., Taylor, L.A., Crozaz, G., 1993. Rare-earth element selenochemistry of immiscible liquids and zircon at apollo-14-an ion probe study of evolved rocks on the moon. Geochimica et Cosmochimica Acta 57, 1143-1149. 
Soldatos, T., Koroneos, A., Kamenov, B., Peytcheva, I., von Quadt, A., Christofides, G., Zheng, X., Sang, H., 2008. New U-Pb and Ar-Ar mineral ages for the Barutin-BuynovoElatia-Skaloti-Paranesti batholith (Bulgaria and Greece): refinement of its debatable age. Geochemistry Mineralogy and Petrology 46, 85-102.

Stolz, A.J., Jochum, K.P., Spettel, B., Hofmann, A.W., 1996. Fluid- and melt-related enrichment in the subarc mantle: evidence from $\mathrm{Nb}$ /Ta variations in island arc basalts. Geology 24 (7), 587-590

Strashimirov, S., Serafimovski, T., Kovachev, V., 1996. Temperatures of the ore-forming processes in the Buchim porphyry copper deposit (Macedonia): data from fluid inclusion studies. Geology of Ore Deposits 38, 333-337.

Strmic Palinkas, S., Palinkas, L.A., Renac, Ch., Spnagenberg, J.E., Lueders, V., Molnar, F., Maliqi, G., 2013. Metallogenic model of the Trepca Pb-Zn-Ag skarn deposit, Kosovo: evidence from fluid inclusions, rare earth elements, and stable isotope data. Economic Geology 108 (1), 153-162.

Sun, S.S., McDonough, W.F., 1989. Chemical and isotopic systematics of oceanic basalts: implications for mantle composition and processes. Geological Society, London, Special Publications 42, 313-345.

Ustaszewski, K., Schmid, St, Fuegenschuh, B., Tischler, M., Kissling, E., Spakman, W., 2008. A map-view restoration of the Alpine-Carpathian-Dinaridic system for the Early Miocene. Swiss Journal of Geosciences. http://dx.doi.org/10.1007/s00015-008-1288-7, 1-21.

van Achterbergh, E., Ryan, C., Jackson, S.E., Griffin, W.L., 2001. Appendix 3 data reduction software for LA-ICP-MS. In: Sylvester, P. (Ed.), Laser-Ablation-ICP-MS in the Earth Sciences. Mineralogical Association of Canada, Short Course, pp. 239-243.

van Hinsbergen, D.J.J., Langereis, C.G., Meulenkamp, J.E., 2005. Revision of the timing, magnitude and distribution of Neogene rotations in the western Aegean region. Tectonophysics 396, 1-34.
Van Hinsbergen, D.J.J., Schmid, St, 2012. Map view restoration of Aegean-West Anatolian accretion and extension since Eocene. Tectonics 31. http://dx.doi.org/10.1029/ 2012 TC003132.

Vernon, R.H., Etheridge, M.A., Wall, V.J., 1988. Shape and microstructure of microgranitoid enclaves-indicators of magma mingling and flow. Lithos 22, 1-11.

Volkov, A.V., Serafimovski, T., V. S., 2010. Formation mechanism of dwarfish Cu-Au porphyry deposits of Macedonia. Doklady Akademii Nauk 431, 6.

von Quadt, A., Moritz, R., Peytcheva, I., Heinrich, C.A., 2005. Geochronology and geodynamics of Late Cretaceous magmatism and $\mathrm{Cu}-\mathrm{Au}$ mineralization in the Panagyurishte region of the Apuseni-Banat-Timok-Srednogorie belt, Bulgaria. Ore Geology Reviews 27, 95-126.

Willingshofer, E., Andriessen, E., Cloetingh, S., Neubauer, F., 2001. Detrital fission track thermochronology of Upper Cretaceous syn-orogenic sediments in the South Carpathians (Romania): inferences on the tectonic evolution of a collisional hinterland. Basin Research 13, 379-395.

Winchester, J.A., Floyd, P.A., 1977. Geochemical discrimination of different magma series and their differentiation products using immobile elements. Chemical Geology 20 (4), 325-343.

Yanev, Y., Boev, B., Doglioni, C., Innocenti, F., Manetti, P., Pecskay, Z., Tonarini, S., D'Orazio, M., 2008. Late Miocene to Pleistocene potassic volcanism in the Republic of Macedonia. Mineralogy and Petrology 94, 45-60.

Zimmerman, A., Stein, H.J., Hannah, J.L., Kozelj, D., Bogdanov, K., Berza, T., 2008. Tectonic configuration of the Apusini-Banat-Timok-Srednogorie belt, Balkans-South Carpathians, constrained by high precision Re-Os molybdenite ages. Mineralium Deposita 43, 1-21.

Zindler, A., Hart, S., 1986. Chemical geodynamics. Annual Review of Earth and Planetary Sciences 14, 493-571. 